\title{
DEMOCRACY IN THE WAKE OF THE CALIFORNIA RECALL
}

\section{ELIZABETH GARRETT $^{\dagger}$}

The recall of Governor Gray Davis and simultaneous election of Arnold Schwarzenegger provide a unique window into aspects of elections and democratic institutions that are not limited to statewide recall elections. Although one must be wary of drawing general conclusions about the political process from an unusual event such as the statewide recall, this election can serve as a way to think about broader issues relevant not only to future recalls but also to all candidate and issue elections in California and throughout the nation. In this article, I will discuss insights that the recent recall provides with respect to four familiar areas of law and politics. First, the recall demonstrated the significant and sometimes troubling role that money plays in modern campaigns, as well as the difficulty of constructing effective and comprehensive campaign finance laws. Second, the unusual structure of the recall election, where an election for Davis's successor was on the same ballot as the recall question, helps to illustrate the role of political parties in elections. It suggests that independent and minor party candidates can be part of an election without necessarily causing widespread voter confusion. Third, the more than twenty lawsuits filed before the election was held-with one threatening to delay the election for months until an en banc panel of the Ninth Circuit stepped in-demonstrate that litigation is being used more aggressively as political strategy ${ }^{1}$ in the wake of the Supreme Court's intervention in the 2000 presidential election. ${ }^{2}$ Unless courts take a less

\footnotetext{
${ }^{\dagger}$ Professor of Law, University of Southern California; Director, USC-Caltech Center for the Study of Law and Politics. I appreciate the helpful comments of Shaun Bowler, Rick Hasen, Pam Karlan, Andrei Marmor, Eric Posner, and participants at the Symposium of the Law of Democracy at the University of Pennsylvania Law School. I also benefited from the excellent research assistance of Bethany Woodard.

${ }^{1}$ Rick Hasen used this phrase in a symposium on reform of the recall process held at USC Law School on October 21, 2003. I have used his term here and will expand on the notion. For coverage of this event, see Laura Mecoy, Scholars, Officials Urge Recall Changes, SACRAMENTO BeE, Oct. 22, 2003, at A3, available at http://www.sacbee.com/ content/politics/recall/story/7645523p-8585866c.html (last visited Sept. 20, 2004).

${ }^{2}$ Bush v. Gore, 531 U.S. 98 (2000). For my criticism of the Supreme Court's involvement in that election, see Elizabeth Garrett, Leaving the Decision to Congress, in THE Vote: Bush, Gore And the Supreme Court 38 (Cass R. Sunstein \& Richard A. Epstein eds., 2001).
} 
activist role in cases affecting elections, this disturbing trend is likely to continue. Finally, I will conclude with a discussion of the interaction between direct democracy and representative democracy. In states with a hybrid system like California, these two forms of democracy influence each other-a reality that we witnessed in the days before the recall election and that we are likely to continue to see as Governor Schwarzenegger threatens to use initiatives to pressure a recalcitrant legislature to do his bidding.

\section{MONEY, THE RECALL, AND ELECTIONS}

California adopted a statewide recall process in 1911 as part of an effort by John R. Haynes and other progressives to implement a system in which corrupt officials at both the local and state levels, particularly those beholden to the mighty Southern Pacific Railroad, could be removed before a regularly scheduled election. ${ }^{3}$ Before the successful recall attempt in 2003, groups had attempted to qualify a gubernatorial recall for the California ballot thirty-one times, including a previous attempt aimed at Gray Davis in his first term, but all those efforts had been unsuccessful. ${ }^{4}$ The California Constitution requires that petition circulators gather signatures equal to $12 \%$ of those who voted in the last gubernatorial election. ${ }^{5}$ Because turnout had been so low in the lackluster general election between Davis and Republican Bill Simon, the recall forces needed to collect just 897,158 valid signatures to qualify the recall for the ballot. ${ }^{6}$ Even with that relatively low threshold, the drive would not have succeeded, at least in placing the recall on the ballot in the fall rather than in March when conditions would have been more favorable to Davis, without the support of an

\footnotetext{
${ }^{3}$ See Thomas E. Cronin, Direct Democracy: The Politics of Initiative, REFERENDUM, AND RECALL 130-32 (1989) (detailing the spread of the recall movement from the Los Angeles city level to the entire state of California); see also Joshua Spivak, California's Recall: Adoption of the "Grand Bounce" for Elected Officials, 81 CAL. HIST. 20, 26 (2004) ("Most Progressives considered it critical to extend the recall to judges, since abuses of judicial power helped maintain the success of the Southern Pacific machine.").

${ }^{4}$ Shaun Bowler \& Bruce Cain, Introduction-Recalling the Recall: Reflections on California's Recent Political Adventure, 37 PS: POL. SCI. \& POL. 7, 7 (2004).

${ }^{5}$ CAL. CONST. art. II, $§ 14(\mathrm{~b})$.

${ }^{6}$ CAL. SEC'y OF State, FAQS About Recalls [hereinafter FAQS About RecAlls], at http://www.ss.ca.gov/elections_recall_faqs.htm (last visited Sept. 20, 2004); see also California Recall Backers Say They Have the Signatures, USA TODAY, July 8, 2003 (reporting that recall supporters had surpassed the 897,158 signatures needed to force a recall election), available at http:/ /www.usatoday.com/news/politicselections/2003-07-08-davis-recall_x.htm (last visited Sept. 20, 2004).
} 
ambitious legislator, Republican Darrell Issa, who contributed around $\$ 2$ million to help foot the bill for paid circulators. ${ }^{7}$ The sophisticated initiative industry in California includes companies that offer clients a money-back guarantee if they do not produce enough valid signatures to qualify something for the ballot; in return, they are paid about $\$ 1.50$ per signature. ${ }^{8}$

Since the Supreme Court held laws banning paid circulators unconstitutional, ${ }^{9}$ a group seeking ballot qualification can be certain of success if it is willing to pay enough. Money is a sufficient condition for ballot access, although it does not assure that the ballot question will pass. Grassroots groups with broad-based support and energized members can still rely on volunteers to gather enough signatures, but even these groups are increasingly turning to paid circulators because of the guarantee of success. Recalls are no different from initiatives in this way-with $\$ 2$ million dollars in their war chest, the pro-recall groups easily exceeded the signature threshold by a considerable amount. In the end, they turned in petitions with more than 1.36 million valid signatures. ${ }^{10}$

The great influence that money wields in the qualification stage of direct democracy has justifiably led to calls for reform. As Daniel Lowenstein has argued, capitalism is a strange way to allocate ballot access in a democracy ${ }^{11}$ (unless one is willing to defend the dubious proposition that wealth corresponds to merit in the political realm),

${ }^{7}$ See Daniel B. Wood, Recall Heard 'Round the Country?, CHRISTIAN SCI. MONITOR, July 15, 2003 (“[M]any national observers-including prominent conservatives-say the recall could never have happened without the support of millionaire businessman Rep. Darrell Issa, who bankrolled the effort...."), available at http://www.csmonitor.com/2003/0715/p01s01-uspo.html (last visited Sept. 20, 2004).

${ }^{8}$ See Elizabeth Garrett, Money, Agenda Setting, and Direct Democracy, 77 TEX. L. REv. $1845,1851-52$ (1999) (noting the existence of agencies that specialize in signature gathering). In the recall, signature gatherers were paid $\$ 1.00$ to $\$ 1.25$ per signature, "virtually guarantee [ing] the recall petition's success." Bowler \& Cain, supra note 4, at 8.

${ }^{9}$ See Meyer v. Grant, 486 U.S. 414 (1988) (holding that a Colorado statute banning payment of petition circulators violated the First and Fourteenth Amendments).

See CAl. SeC'y of State, Recall Signature Update, at http://www.ss.ca.gov/ elections/recall_sigs.htm (July 31, 2003) (stating also that more than 1.6 million signatures were submitted).

${ }^{11}$ Daniel H. Lowenstein, Comments at the Post-Mortem Conference on the Recall at USC Law School (Nov. 14, 2003) (student notes available at http://lawweb.usc.edu/ cslp/conferences/post-mortem_recall_03.html (last visited Sept. 20, 2004)). For a survey of the scholarship on the role of money in initiative campaigns, see Elizabeth Garrett \& Elisabeth R. Gerber, Money in the Initiative and Referendum Process: Evidence of its Effects and Prospects for Reform, in THE BATTLE OVER Citizen LAWMAKING: A COLLECTION OF ESSAYS 73, 76-82 (M. Dane Waters ed., 2001). 
but the reality is that money can buy a place on the ballot, even if it cannot entirely determine the outcome of the election. Many of the reform proposals ostensibly designed to respond to the influence of money, including those currently being discussed in California in the wake of the recall, would simply raise the signature threshold. California's threshold for a statewide recall is the lowest in the nation, ${ }^{12}$ and it is lower even than California's requirements for recalls of state legislators and judges. To recall those officials, petition gatherers need signatures equal to $20 \%$ of the votes cast in the official's electoral district. ${ }^{13}$

The most substantial reform proposal, a constitutional amendment proposed by Assemblyman Mark Ridley-Thomas, would require signatures equal to $12 \%$ of persons registered to vote at the last election-not those who actually voted-to place a gubernatorial recall on the ballot. ${ }^{14}$ This would change California from the most permissive state to one of the most rigorous states, and not surprisingly RidleyThomas was a vocal opponent of the recall process. Other proposals for reform would bring California in line with other states and require circulators to gather signatures equal to $25 \%$ of those who voted in the last election. ${ }^{15}$

Whether California's relatively low threshold for a gubernatorial recall is too low is unclear. After all, there has been only one effort that has qualified for the ballot in ninety years, and for the past several decades, the initiative industry in California has surely been sophisticated enough to realize that a substantial war chest could qualify a recall just as it can an initiative. Nothing in the law or constitution changed in 2003 that made a recall suddenly more possible than it was five or ten years before, although the low turnout in the 2002 general election meant that fewer signatures were required to meet the $12 \%$ threshold. The success of the 2003 recall has made the process sali-

${ }^{12}$ See Bruce E. Cain, Commentary, Do Better Next Time: The State's Recall Laws Clearly Could Use a Little Tweaking, L.A. TIMES, Aug. 17, 2003, at M5 (noting that most of the eighteen states with provisions for recalling a governor require the number of recall petition signatures to be at least $25 \%$ of the vote in the last election, and that six of these states use eligible voters, not actual voters, as the "threshold measure").

${ }^{13}$ CAL. CONST. art. II, § 14(b).

${ }^{14}$ See Assemb. Const. Amend. 20, 2003-04 Leg., Reg. Sess. (Cal. proposed Sept. 9, 2003).

${ }^{15}$ See Cain, supra note 12 (discussing the greater percentage of signatures required to initiate a recall in certain states); Rick Hasen, Elect to Resolve Balloting Quandary: Numerous Suits Challenging Vote Indicate State's Recall Laws Are in Chaotic Mess, L.A. DAILY J., Aug. 18, 2003, at 6 (suggesting that "percentages should be increased to $25 \%$ as it is in most states"). 
ent; thus, it is likely that we will see an increase in the attempts to qualify statewide recalls. Nonetheless, any substantial increase in the number of signatures seems motivated more by a dislike of direct democracy than by a genuine desire to improve the process. In essence, these proposals reduce the number of recalls by raising the cost of petition drives. Rather than increasing the price of ballot access, thereby ensuring that only the well funded will have the ability to use the recall tool, policymakers and voters should formulate reforms consistent with the purpose of direct democracy.

The goal of direct democracy, whether ever realized or not, ${ }^{16}$ is to allow the people to circumvent the traditional legislative process when it is dominated by powerful narrow interests. Although representing only a minority, such interest groups can disproportionately affect the legislative process either by taking advantage of vetogates to block change or by gaining benefits through logrolling. Elected officials may be extremely attentive to the wishes of organized groups with intense preferences because these groups have the ability to monitor the legislature closely and to reward their supporters with campaign contributions and other benefits. The initiative, referendum and recall processes are intended to give grassroots movements that plausibly represent majority wishes methods to discipline elected agents when they are more responsive to minority interests rather than to the larger electorate. The design of direct democracy should be consistent with the objective of empowering the relatively unorganized many as they combat the clout of the organized but impassioned few in the legislative arena.

Signature thresholds were intended to serve as a signal of significant grassroots support for an issue before it was elevated to the ballot. At the time this mechanism was chosen as the triggering event for ballot access, the drafters of direct democracy provisions did not envision the widespread use of paid circulators or the involvement of a professionalized initiative industry of consultants. Simply raising the thresholds in response to the new reality may mean that fewer recalls will occur, but it does not serve the populist objectives of direct democracy. Instead, it strengthens the hand of those who can afford to

\footnotetext{
${ }^{16}$ See Daniel A. Smith \& Joseph Lubinski, Direct Democracy During the Progressive Era: A Crack in the Populist Veneer?, 14 J. POL'y HIST. 349, 360-61 (2002) (describing the use of direct democracy initiatives by corporate interests in Colorado in 1912); see also Daniel A. Smith, Campaign Financing of Ballot Initiatives in the American States, in DANGEROuS DEMOCRACY? THE BATTLE OVER BALlot INITIATIVES IN AMERICA 71, 73 (Larry J. Sabato et al. eds., 2001) (discussing the structural problems with the ballot initiative process that has allowed special interests to dominate direct democracy initiatives).
} 
spend substantial money on a petition drive and makes it even harder for all-volunteer efforts to succeed. For example, had it been in place in 2003, the Ridley-Thomas proposal would have required a successful recall drive to get more than 1.8 million signatures-more than double that required to qualify the Davis recall. ${ }^{17}$ Raising signature thresholds alone means that many groups will be priced out of the market, including many truly grassroots groups. Thus, the few issues that qualify for the ballot will most certainly be the product of special-interest money and organization. Such ballot questions may not be able to win in the election, ${ }^{18}$ although savvy groups will work to qualify issues that resonate with voters and to frame ballot questions so that they seem consistent with the majority's preferences. Furthermore, merely qualifying a recall and triggering an election may be sufficient to disrupt the political process in a way that serves proponents' interests, regardless of the outcome. ${ }^{19}$

More creative reform is required to reconfigure the ballot access process so it serves the populist objectives of recall and initiative. For example, Daniel Lowenstein and Robert Stern have proposed a volunteer bonus system that would require groups using paid workers to obtain more signatures than groups exclusively using volunteers. ${ }^{20}$ There are limitations to this proposal, and it may run afoul of the First Amendment. ${ }^{21}$ Nonetheless, it is a promising idea, it is more consistent with the goals of recall and initiative, and it might pass constitutional muster if justified by reference to the purpose of signature thresholds. Thresholds are designed to demonstrate popular support.

${ }^{17}$ See CAl. SEC'y of State, Report of the Registration for November 2002 GENERAL ELECTION (reporting that 15,303,469 individuals were registered to vote in the 2002 California gubernatorial election), available at http://www.ss.ca.gov/elections/ ror_102102.htm (Oct. 21, 2002). Some observers believe that the Davis recall forces would have been able to meet the higher threshold. See John M. Broder, Bill Is Proposed to Revise California's Recall Process, N.Y. TIMES, Oct. 22, 2003, at A17 ("Given Mr. Davis's unpopularity and the determination and deep pockets of the forces behind the recall, it is probable that its proponents would have met that threshold as well."); Hasen, supra note 15, at 6 ("Even with that higher number, the Gray Davis recall likely would have qualified ....").

${ }^{18}$ See generally Elisabeth R. Gerber, The POPUlist PARAdOX: InTEREST Group INFLUENCE AND THE PROMISE OF DiReCt Legislation (1999) (discussing the need for grassroots support to win most initiative elections and detailing the power and limitations of money and economic interest groups).

${ }^{19}$ Cf. Garrett, supra note 8, at 1856-63 (discussing "spillover" effects of merely qualifying an initiative for the ballot).

${ }^{20}$ Daniel Hays Lowenstein \& Robert M. Stern, The First Amendment and Paid Initiative Petition Circulators: A Dissenting View and a Proposal, 17 Hastings CONST. L.Q. 175, 221 (1989).

${ }^{21}$ See Garrett, supra note 8, at 1874-76 (assessing the volunteer bonus proposal). 
Groups that can persuade people to volunteer to circulate petitions have already produced one convincing signal of such support and should not need to gather as many signatures as an additional sign of popularity.

Lowenstein has also suggested requiring that those who support a recall or initiative campaign go to a firehouse, library, or other public location to sign the petition. As part of this proposal, he supports reducing the number of signatures required for ballot qualification because the greater effort required to sign an initiative would provide a reliable indicator of support and thus the importance of the signal of mere numbers would be reduced. ${ }^{22}$ Making it more costly for voters to sign a petition-in terms of opportunity costs-would make signatures more meaningful. It would be difficult for paid circulators to convince people to expend their time and energy traveling to a petition site unless the potential signers really supported the ballot question. In contrast, petition circulators report that they can convince voters to take a minute or two to sign almost any petition on their way into a Wal-Mart or during a stroll through a shopping center. Lowenstein's proposal is consistent with the objectives of direct democracy in a way that the more typical proposals to increase signature thresholds are not. Of course, it is not foolproof. Presumably, well heeled interests could provide voters with transportation to and from the venues where petitions are available; however, it is less likely that voters who care nothing about the ballot issue would be willing to take the bus to the firehouse. Remember that although petition circulators can be paid, those who sign petitions cannot be compensated.

Other interesting reform proposals would allow voters to "sign" petitions on the Internet, thereby reducing the cost of ballot qualification and allowing grassroots groups to qualify issues for the ballot more easily. This reform would result in many more recalls and initiatives and would not eliminate the influence of money, but it would open the process up to grassroots groups with widespread popular support. The innovative use of the Internet by Howard Dean in his unsuccessful quest for the Democratic presidential nomination revealed that it can be a powerful tool to harness real grassroots support. For example, more than $59 \%$ of the over $\$ 51$ million raised by Dean

\footnotetext{
${ }^{22}$ Lowenstein, supra note 11; see also Daniel H. Lowenstein, Election Law Miscellany: Enforcement, Access to Debates, Qualification of Initiatives, 77 TEX. L. REV. 2001, 2007-08 (1999) (explaining that requiring voters to travel to a specified location where the petitions could be signed would "make signing a petition about as difficult (and about as easy) as voting").
} 
in the first quarter of 2004 came in increments of $\$ 200$ or less, ${ }^{23}$ many of which were raised online. ${ }^{24}$ Any reform of direct democracy that uses the Internet to empower grassroots movements should be accompanied by an increase in the signature threshold, and perhaps it could also be combined with a volunteer bonus approach. Substantially increasing the signature threshold is a defensible reform only if it is passed together with a change in circulation methods which favors, or at least does not disadvantage, grassroots organizations.

One other reform to combat the role of money in petition drives, which should be adopted with other proposals, is to require that paid circulators wear badges identifying them as PAID and also providing information about which groups or individuals are footing the bill. ${ }^{25}$ Information that the circulator is a hired gun may well turn some voters off and make signature gathering more difficult. Politicians believe such information affects voter behavior because they work to publicize that their opponents are using paid circulators as a way to tarnish a petition drive and defeat the ballot question. A badge designating a circulator as PAID might encourage voters to ask about the source of the payment, thereby alerting them to the interests behind the petition drive. In issue elections, an effective voter shortcut is provided by information that reveals which groups support and which oppose an initiative and the intensity of their views. ${ }^{26}$ A signal like a PAID badge, which prompts further inquiry, may provide voters with information that allows them to reach better conclusions about whether they support placing a particular question on the ballot. Furthermore, if there is a stigma associated with paid circulators, then this

\footnotetext{
${ }^{23}$ Press Release, State PIRGs, The State PIRGs' Democracy Campaigns, Explosion in Presidential Candidates' Fundraising Overshadows 527 Soft Money: Small Donors Increasing Numbers, but Big Money Still Dominates (Apr. 22, 2004), available at http://www.pirg.org/democracy/democracy.asp?id2=13066 (last visited Sept. 20, 2004).

${ }^{24}$ See Howard Dean, Opinion, We the People (Who Write Small Checks), Wall ST. J., Nov. 10, 2003, at A16 (describing the successful small-dollar online fundraising of the Dean campaign).

${ }^{25}$ The constitutionality of the requirement that circulators wear badges identifying them as PAID or VOLUNTEER was not determined by the Supreme Court in Buckley $v$. American Constitutional Law Foundation, Inc., 525 U.S. 182 (1999). The Court struck down the requirement that the circulators' names had to appear on the badge, but it did not rule on the paid/volunteer label itself. $I d$. at 197.

${ }^{26}$ See Michael X. Delli Carpini \& Scott KeEter, What Americans Know ABOut POLITICS AND WHY IT MATTERS 51 (1996) (describing voters' use of simplifying heuristics, such as a ballot initiative's newspaper endorsements or a candidate's group memberships, to draw conclusions about a political issue or candidate); Arthur Lupia, Shortcuts Versus Encyclopedias: Information and Voting Behavior in Califormia Insurance Reform Elections, 88 AM. POL. SCI. REV. 63, 72 (1994) (studying voting cues in initiative elections affecting the insurance industry).
} 
information alone, which is apparent from the badge, could reduce the effectiveness of money in petition drives. ${ }^{27}$

Money was an important part of the 2003 recall story not just in the qualification stage, but also in the campaign itself. The role of money in the campaign and the sources of money used by candidates and recall organizations reflect the influence of money generally in candidate and issue elections. The bifurcated nature of the recall election meant that the regulatory regime for campaign finance in the campaign was bifurcated as well. Only those candidates running for governor in the second part of the election were limited by the state's campaign laws to accepting contributions no greater than $\$ 21,200$ from each individual. Committees formed to campaign for or against the recall-even those controlled by candidates or by Gray Daviswere not subject to contribution limits, although they were required to comply with disclosure rules. This reality led to a variety of strategies by candidates to evade the effect of contribution limitations.

First, very wealthy candidates could spend as much of their own money as they wished because Supreme Court jurisprudence has disallowed expenditure limits while upholding contribution limits. ${ }^{28}$ The largest single contributor in the entire election was Arnold Schwarzenegger, who spent over $\$ 10.5$ million of his own money, mainly through his "Californians for Schwarzenegger" committee. ${ }^{29}$ The theme of his successful campaign was that he would stand for the people against special interests, and, as part of that strategy, he announced that he would not take money from special interests but would instead spend his own money. He is rich enough, he told voters, that he would be beholden to no one. ${ }^{30}$ In the end, he did accept substantial campaign contributions from a variety of interests including real estate developers, car dealers, insurance interests, and financial institutions. $^{31}$ It turned out that his definition of "special interests" included

27 See Garrett, supra note 8, at 1881-87 (discussing such a reform).

${ }^{28}$ Scholarly criticism of this bifurcated judicial treatment is voluminous. For a particularly good treatment, see Kathleen M. Sullivan, Political Money and Freedom of Speech, 30 U.C. DAVIS L. REV. 663 (1997).

${ }^{29}$ See CAL. SEC'Y OF StATE, CAMPAIGN FInANCE ACTIVITY: ARNOLD SCHWARZENEGGER, at http://cal-access.ss.ca.gov/Campaign/Committees/Detail.aspx?id=1012569 (last visited Sept. 20, 2004) (detailing the contributions made by Schwarzenegger during the final quarter of 2003).

${ }^{30}$ See Tom Elias, Opinion, Arnold's Story Isn't Consistent, Palo Alto Dally News, Feb. 18, 2004, at 10 (noting Schwarzenegger's boast about not needing campaign donations).

31 See Bowler \& Cain, supra note 4, at 8 (detailing amounts of contributions from these groups). Schwarzenegger has continued to raise substantial money from these 
only Indian tribes and labor unions. ${ }^{32}$ However, he also self-financed a great portion of his campaign, demonstrating the advantages for multimillionaires willing to spend their own money in a campaign system where contributions from others are limited but overall expenditures are not. It is not clear that Schwarzenegger needed to spend so much money in political advertising, because the celebrity status that allowed him to amass wealth also ensured him virtually unlimited media attention, not only from the traditional news outlets but also from entertainment shows and the international press corps.

Other millionaire candidates who spent substantial sums on their campaigns were Peter Ueberroth, a Republican running as an independent who ultimately dropped out of the race, and Garrett Gruener, a virtually unknown candidate who spent about $\$ 460$ for each vote he received. ${ }^{33}$ Thus, being a millionaire willing to spend money on a campaign is not a sufficient condition for electoral success, but it is increasingly a necessary one given the structure of the campaign finance rules.

A second evasive tactic for candidates was to take advantage of loopholes in the rules regulating campaign finance in candidate elections. The combination of contribution limitations and millionaire competitors led Cruz Bustamante, the Democratic Lieutenant Governor, to resort to questionable, and ultimately impermissible, tactics to evade the $\$ 21,200$ cap on contributions. Unlike the new federal law, ${ }^{34}$ the California campaign laws do not increase contribution limits for those who are running against self-financed millionaires. In fall 2003, Bustamante still had an active campaign account that had been estab-

groups since the election. See Dan Morain, Governor Raises $\$ 1$ Million Since Election, L.A. TIMES, Nov. 18, 2003, at A20 (updating the governor's fundraising results).

${ }^{32}$ See Aurelio Rojas \& Margaret Talev, Campaign Loans Are Targeted, SACRAmENTO BEE, Oct. 2, 2003 (discussing Schwarzenegger's acceptance of funds from anyone except Indian tribes and labor unions), available at http://www.sacbee.com/content/ politics/recall/story/7522468p-8464221c.html (last visited Sept. 20, 2004); see also Elias, supra note 30, at 10 ("Schwarzenegger has taken tens of millions from business interests after conveniently claiming they are not special interests.").

${ }^{33}$ See Dan Morain \& Joel Rubin, Financially, the Recall was Business as Usual, L.A. TIMES, Oct. 10, 2003, at A24 (outlining the amounts spent by various candidates in the recall election).

${ }^{34}$ See Jennifer A. Steen, The "Millionaires' Amendment," in LIFE AFTER REFORM: When the Bipartisan CAMPaign Reform ACt MeEts Politics 159, 159 (Michael J. Malbin ed., 2003) (discussing likely consequences of the federal provision). The constitutionality of this provision was not decided in the recent case upholding most provisions of the Bipartisan Campaign Reform Act of 2002 (BCRA), Pub. L. No. 107-155, 116 Stat. 81 (codified in scattered sections of 2, 18, 28, 36, 47 U.S.C.). See McConnell v. FEC, 540 U.S. 93, 124 S. Ct. 619, 710 (2003) (finding provision nonjusticiable). 
lished before the enactment of the current restrictions. He argued that the campaign finance limitations did not apply to contributions made to that account. This account took nearly $\$ 4$ million from donors who exceeded the contribution limit, including $\$ 1.5$ million from the Viejas Tribal Government, an Indian tribe with substantial interests in casinos. ${ }^{35}$ Tribes and organized labor also spent $\$ 6.3$ million in independent expenditures to support Bustamante; ${ }^{36}$ contribution limits do not apply to funds raised for such expenditures.

Bustamante's efforts to evade the contribution limits may be understandable given the wealth of his competitors and the shortened campaign period of the recall, but they ultimately backfired. The Lieutenant Governor was attacked in the press and by other candidates as the tool of special interests, an argument that resonated with voters who had been turned off by Davis's similar fundraising connections to interest groups. Like Bustamante, Davis is not personally wealthy, so he could compete against millionaire competitors like Bill Simon only by aggressively raising money from well-heeled interest groups. Ironically, when the populace wants to elect an "ordinary person" who appears to be independent from interest groups, current campaign laws may leave voters only with a field of extraordinarily rich people. Bustamante was successfully sued by a Republican state senator who argued that the Lieutenant Governor could not evade contribution limits by using the old campaign account. ${ }^{37}$ Although by the time of the lawsuit most of the money had been spent for television advertisements and thus had already affected the election, the judicial decision prompted further negative publicity.

\footnotetext{
${ }^{35}$ Cal. Common Cause, Top Contributors to Bustamante 2002 Committee FOR LIEUTENANT GOVERNOR, at http://recallmoneywatch.com/recallwatch/detail/ recalldetail.html?type $=$ allcontributors\&stype $=$ each\&id $=980194$ (last visited Aug. 30, 2004).

${ }^{36}$ Dan Morain, Recall Campaigners Spend $\$ 88$ Million, Despite Limits, L.A. TIMES, Feb. 4, 2004, at B6.

37 Johnson v. Bustamante, No. 03AS04931, 2003 WL 23782188 (Cal. Super. Ct. Sept. 22, 2003) (granting preliminary injunction). In addition, the Fair Political Practices Commission (FPPC) sued Bustamante for his use of the old campaign committee to evade contribution limits. Nancy Vogel, Bustamante Accused of Violations, L.A. TIMES, Jan. 8, 2004, at B1 (noting that the FPPC filed civil suit "because [FPPC] officials considered the alleged violations egregious and deserving of tougher penalties that could be obtained only in court"). This latter case was settled when Bustamante agreed to pay a $\$ 263,000$ penalty, the largest ever paid for a violation of the state's campaign finance law. The fine was paid with extra campaign funds by Bustamante's campaign committee. Tim Reiterman \& Jennifer Warren, Lt. Gov. Agrees to Pay Hefty Fine, L.A. TIMES, Apr. 14, 2004, at B1.
} 
A third method of evasion was possible because the election for governor was held at the same time as an election on two initiatives and on the recall itself. Contributions relating to direct democracywhether to an initiative or to the recall election-are not limited by state law. To counteract charges of inappropriate special interest influence but still get some benefit from the large contributions from tribes and labor unions, Bustamante tried to take advantage of this bifurcation. He transferred the money collected in his old campaign account, in violation of the rules applying to candidate elections, to a committee he organized to oppose Proposition 54, the "Racial Privacy Initiative." ${ }^{38}$ This initiative, the brainchild of anti-affirmative action activist Ward Connerly, would have prohibited the state from gathering data which classified people by race or ethnicity. ${ }^{39}$ The money played a large role in defeating the initiative, a matter important both to Bustamante and his constituents, and it allowed the Lieutenant Governor to spend the money in a way designed also to help his campaign. He appeared in many of the ads, and the people who were likely to turn out to vote against Proposition 54 were also likely to vote for him. Bustamante was not the first California gubernatorial candidate to use an initiative to improve his electoral chances. Jerry Brown used an initiative on campaign finance and lobbying reform to underscore his commitment to clean government, and Pete Wilson used an initiative denying state-provided services to undocumented workers to turn out voters he hoped would also vote for him. ${ }^{40}$

Other candidates used committees organized to oppose or support the recall to raise unlimited amounts of money that they could use to influence both parts of the election. First, recall target Gray Davis raised nearly $\$ 18.3$ million through his antirecall committee "Californians Against the Costly Recall of the Governor," a sum made possible by the absence of contribution limitations. ${ }^{41}$ Thus, because he was operating under different rules than those facing Bustamante,

38 See Alexa H. Bluth, Judge to Bustamante: Prove You Spent Funds, SACRAmento BEE, Sept. 27, 2003, http://www.sacbee.com/content/politics/recall/story/ 7491938p-8434102c.html (last visited Sept. 20, 2004) (reporting that a Sacramento judge ordered Bustamante to account for funds used after they were transferred to the anti-Proposition 54 committee).

39 Proposition 54, Prohibition Against Classifying by Race by State and Other Public Entities, available at http://vote2003.ss.ca.gov/propositions/2-3-prop-54.html (last visited Sept. 20, 2004).

40 David D. SCHMidt, Citizen Lawmakers: The Ballot Initiative Revolution 28 (1989); Peter Schrag, Paradise lost: California's Experience, America's FUTURE 225-34 (1998).

${ }^{41}$ Morain, supra note 36 , at B6. 
Davis, a long-time civil servant and man of modest economic means, was able to legally accumulate a war chest comparable to that of his rich competitor. However, the need to raise large sums of money in this campaign and in past ones, possible in many cases only by going to interests that would be vitally affected by decisions Davis made in office, led to public dissatisfaction with Davis and fueled the recall effort. Thus, his success in fundraising was a double-edged sword in the political realm.

The bifurcated campaign finance system also allowed candidates for governor to form separate pro-recall committees and raise unrestricted money for those efforts. For example, Schwarzenegger's "Total Recall” committee raised over $\$ 4.5$ million that it spent largely on advertisements supporting the recall. ${ }^{42}$ As with Bustamante's ads against Proposition 54, the Total Recall advertisements featured Schwarzenegger as spokesman. Unless a viewer noticed the fine print identifying the sponsor of the ad, she would be hard-pressed to tell the difference between one funded by the Schwarzenegger campaign committee and one paid for by the "Total Recall" committee. Schwarzenegger has continued to use the bifurcation of campaign finance laws to his advantage. He is willing to implement some of his policies through voter initiatives, and he has been active in raising money to fund those efforts. ${ }^{43}$ Schwarzenegger has organized a committee called the "Governor Schwarzenegger's California Recovery Team" that is solely involved in supporting ballot measures vital to implementing the Governor's agenda. ${ }^{44}$ For the first year of his term he was unfettered by contribution limits in fundraising for his ballot ques-

${ }^{42}$ See Cal. Sec'y of State, Campaign Finance Activity: Arnold SchwarZenegger's Total Recall Committee, Vote Yes to Recall Gray Davis, at http:/ /cal-access.ss.ca.gov/Campaign/Committees/Detail.aspx?id=1257330\&session=2003 (last visited Sept. 20, 2004) (outlining contributions to, and expenditures of, the "Total Recall" committee).

${ }^{43}$ For example, on November 17, 2003, at a lunch with the California Chamber of Commerce, the new governor announced plans to use the initiative process to enact various reforms, including a reform of the workers' compensation system. Peter Nicholas \& Joe Mathews, Schwarzenegger Sworn In, Rescinds Car Tax Increase, L.A. TIMES, Nov. 18, 2003, at A1 (discussing the first actions taken by Schwarzenegger after being sworn in); see also infra notes 147-58 and accompanying text (discussing use of initiatives as part of his governing strategy).

${ }^{44}$ See Peter Nicholas, Fundraiser "Unfortunate," Governor's Aides Concede, L.A. TIMES, Feb. 18, 2004, at B6 (discussing the ethical implications of the lack of contribution limits for ballot measures committees); see also CAL. SEC'Y OF STATE, CAMPAIGN FINANCE ACTIVITY: SCHWARZENEGGER's CALIFORNIA RECOVERY TEAM, GOVERNOR, at http://calaccess.ss.ca.gov/Campaign/Committees/Detail.aspx?id=1261406\&session=2003 (last visited Sept. 20, 2004) (listing the total value of contributions made to "Schwarzenegger's California Recovery Team"). 
tions, but it is incredibly naive to think that Schwarzenegger is less grateful to interests that fund ballot questions vital to his agenda (and to his reelection) than to those who contribute directly to his campaign committee.

Thus, the recall campaign presented an unusual example of the usual machinations apparent when candidates devise strategies within a system of some limitations, many loopholes and unregulated channels of money, and different rules for different kinds of campaigns that can nonetheless be run to complement each other. Some loopholes can be closed, as occurred with Bustamante's 2002 campaign committee. In addition, the California Fair Political Practices Commission (FPPC) has announced plans to apply contribution limits to ballot-initiative campaign committees controlled by candidates and office holders. ${ }^{45}$ Effective after November's elections, the new regulations are clearly a response to Schwarzenegger's aggressive exploitation of the bifurcated rules. Supreme Court jurisprudence suggests that fewer limitations on campaign finance are allowed in the context of initiatives than in candidate elections, ${ }^{46}$ so it is likely the new restrictions on issue committees will be challenged in Court. As long as there are states with hybrid systems with some bifurcation of campaign rules, candidates can use ballot questions to influence their elections and to evade some of the restrictions on candidate committees. ${ }^{47} \mathrm{Un}$ regulated avenues for campaign fundraising and spending are increasingly important in the wake of McConnell v. FEC, where the Supreme Court upheld the new federal law that cut off methods used in the past to evade contribution limitations, such as soft money raised by political parties. The recall election dramatically emphasizes the reality of campaign finance regulation: effective regulation is very difficult because wily political actors learn how to take advantage of unregulated avenues of influence. ${ }^{48}$

${ }^{45}$ Gabrielle Banks, New Limits on Initiative Campaigns, L.A. TIMES, June 26, 2004, at B1.

${ }^{46}$ See Citizens Against Rent Control/Coalition for Fair Hous. v. City of Berkeley, 454 U.S. 290, 300 (1981) (holding that a legislative limitation on contributions to committees formed to support or oppose ballot measures contravened First Amendment rights of association and expression); First Nat'l Bank of Boston v. Bellotti, 435 U.S. 765, 775-95 (1978) (finding a Massachusetts statute prohibiting corporate expenditures regarding individual income tax referenda violative of the First Amendment).

${ }^{47}$ For a discussion of the ability of candidates to take advantage of loopholes and unregulated avenues of spending money, see Samuel Issacharoff \& Pamela S. Karlan, The Hydraulics of Campaign Finance Reform, 77 TEx. L. REv. 1705 (1999). See also McConnell v. FEC, 124 S.Ct. 619, 706 (2003) (concluding that " $[\mathrm{m}]$ oney, like water, will always find an outlet").

${ }^{48}$ For a discussion of this pragmatic objection to campaign finance, see Elizabeth 
Even if reformers wanted to plug some of the holes in the regulatory system, it is not clear that contribution limits can be extended fully into a recall campaign. Certainly, some contribution limits can be justified using the state interests that support restrictions in ordinary candidate elections. For example, the incumbent governor is susceptible to quid pro quo corruption in the same way that any candidate for elected office is, as are candidates affiliated with recall committees. Indeed, a sitting governor seeking to retain her job in the face of a recall may be more susceptible to quid pro quo corruption, and certainly she is more able to make credible promises of benefits since she is in office and has the power to immediately reward supporters. Thus, current jurisprudence might support the application of contribution limitations to committees these politicians control, but it is unlikely to support comprehensive campaign finance regulation of other participants in a recall. Not all committees organized to support or oppose the recall are coordinated with candidates; some, and perhaps a good number, are legitimately focused on the recall itself without any connection to either the incumbent or a potential successor. They are more like traditional initiative campaign committees; thus, First Amendment challenges to contribution restrictions are likely to succeed. ${ }^{49}$ Bifurcation of the rules within the recall campaign itself would be undesirable. To apply limits only to groups controlled by the target of the recall and not to many of the committees seeking his ouster seems even more inequitable than the current system for candidate elections where self-financed millionaires are at an advantage relative to those of more modest means. If the FPPC's decision to apply campaign restrictions only to some issue committees, namely those controlled by candidates and officeholders, survives judicial attack, we will develop experience with a different sort of bifurcation of campaign rules and will learn how strategists react to the new regime. These lessons can be applied in the more unusual context of recall campaigns.

Garrett, The Future of Campaign Finance Reform Laws in the Courts and in Congress, 27 OKLA. City U. L. REV. 665, 672-73 (2002).

${ }^{49}$ If McConnell is a signal that the Court may be moving toward accepting a state interest based more on equality concerns or the right for all to participate in selfgovernment, campaign finance regulation beyond disclosure could be permissible in the direct democracy context. See Richard L. Hasen, Buckley Is Dead, Long Live Buckley: The New Campaign Finance Incoherence of McConnell v. Federal Election Commission, 153 U. PA. L. REv. 31, 57-60 (2004) (explaining why McConnell "appears to be a transitional case, with even stronger signals pointing to the participatory selfgovernment rationale"). It is still too early, however, to tell if $\mathrm{McConnell}$ is beginning to articulate new state interest in the regulation of campaign speech that could support contribution and expenditure limits in ballot question contests. 


\section{Political Parties}

One hundred thirty-five candidates appeared on the recall ballot in the election to succeed Governor Davis in the event that he was recalled. $^{50}$ This glut of candidates was made possible by poorly drafted statutes that provided no clear rules for ballot access and by the rules chosen by the Secretary of State in the exercise of his discretion as the chief election officer, which posed only minor hurdles for people seeking to add "Gubernatorial Candidate" to their resumes. ${ }^{51}$ In the early days of recall in California, potential candidates had to obtain signatures equal to $1 \%$ of those who voted in the last election. ${ }^{52}$ At the time of the adoption of this constitutional provision, that requirement meant that candidates would have needed about 4000 signatures. ${ }^{53}$ This provision, originally in the constitution and then placed in statute, was repealed in 1976 and replaced with directions to use "the manner prescribed for nominating a candidate to that office in a regular election." ${ }^{54}$ However, the provision regulating ballot access for primary elections explicitly states that it does not apply to recall elections. ${ }^{55}$

In the face of a conflicting and badly drafted statutory scheme, the Secretary of State determined that the very permissive ballot access rules for primary elections would be used, notwithstanding the express language to the contrary. Thus, candidates needed only to obtain either 65 signatures and pay $\$ 3500$ or to obtain 10,000 signatures. ${ }^{56}$ That opened the door for the multitude of candidates, the majority of whom ran for reasons other than the hope of winning. A few were concerned with broadly publicizing particular political issues or concerns. Some, like Gary Coleman, the former child actor, Mary Carey, the current porn star, and Gallagher, the melon-smashing comedian, ran to enhance their visibility in other careers. Perhaps many ran to be able to claim at future family reunions that they once were candidates for governor.

\footnotetext{
${ }^{50}$ Official Sample Ballot and Voter Instructions, October 7, 2003 Special Election (on file with author).

${ }^{51}$ Fredric Woocher, Comments at the Post-Mortem Conference on the Recall at USC Law School (Nov. 14, 2003) (student notes available at http://lawweb.usc.edu/ cslp/conferences/post-mortem_recall_03.html (last visited Sept. 20, 2004)).

${ }^{52} I d$.

${ }^{53} \mathrm{Id}$.

${ }^{54}$ CAL. ElEc. CODE $§ 11381$ (West 2003); see also Burton v. Shelley, No. S117834, 2003 WL 21962000, at *4-5 (Cal. Aug. 7, 2003) (providing the drafting history of the ballot access provisions for recall election).

${ }_{55}$ CAL. Elec. CODE $\$ 8000$ (West 2003).

${ }^{56}$ FAQS ABOUT RECALls, supra note 6.
} 
This ballot, unusual in statewide races which typically feature two or a few more candidates for each position, ${ }^{57}$ is noteworthy for more than the carnival aspect of dozens of candidates listing interesting professions such as "retired meat packer," "fathers' issues author," and "marijuana legalization attorney." 58 Two other features deserve mention because of their relevance in more typical elections. First, the long and unusual ballot presents a case study of the potential for voter confusion. Second, the lack of party control over access to the general election ballot had significant effects on which candidates appeared on the ballot and which were frontrunners. To take the most dramatic example, Arnold Schwarzenegger, who might not have survived a closed party primary, is now the Governor of California.

This election is a case study of unusual ballots and the potential for voter confusion. Judges dealing with challenges to strict ballot access provisions are often faced with claims by state officials that the possibility of voter confusion justifies rigorous regulation of who can get on the ballot. Defenders of access restrictions argue that voters confronted with a ballot containing many candidates for one office, or with ballot notations beyond party affiliation, will not be able to vote accurately because they will be overwhelmed. Virtually none of the judicial cases includes actual evidence of voter confusion; instead, mere assertion of this phenomenon is usually accepted as a sufficient state interest to protect the regulation from constitutional attack. ${ }^{59}$

The recall ballot provides a good test of whether relatively unlimited ballot access results in confused voters. The ballot had other features that might be expected to contribute to confusion. It provided next to each candidate's name a notation of party affiliation and occupation. ${ }^{60}$ Furthermore, candidates were listed in random order, to

${ }^{57}$ Large numbers of candidates are not unheard of in races for local elections. See, e.g., Sherry Bebitch Jeffe, Opinion, The Name Game: With 52-Count 'Em 52-People Running for Office, Will a Vision of L.A. Be Lost in the Shuffle?, L.A. TimES, Feb. 7, 1993, at M1 (discussing Jerry Brown's election to the Los Angeles Community College Board in 1969 out of a field of 133 candidates).

${ }_{58}$ Official Sample Ballot and Voter Instructions, supra note 50.

${ }^{59}$ See, e.g., Timmons v. Twin Cities Area New Party, 520 U.S. 351, 370 (1997) (holding that antifusion laws prohibiting candidates from being affiliated on a ballot with multiple political parties do not violate First and Fourteenth Amendment associational rights); Munro v. Socialist Workers Party, 479 U.S. 189, 195-96 (1986) (finding constitutional a Washington statute providing that minor party candidates who receive less than one percent of votes cast in a primary election can not have their names placed on general election ballots).

${ }^{60}$ See Monika L. McDermott, Candidate Occupations and Voter Information Shortcuts (2003) (unpublished manuscript, on file with author) (assessing the importance of information about a candidate's occupation as a voting cue). 
minimize first-order effects, ${ }^{61}$ and the order was changed from district to district, meaning that effective voter education using sample ballots had to be different in each district. Finally, voting technology in some counties further complicated the ballot; for example, punch card ballots required seven pages to list all the candidates. Election officials worried that voters would try to vote for one candidate per page, rather than just one in the list of 135.

Many observers predicted confusion in large part because of the ballot design, but also because of the reduced numbers of polling places, some of which were relocated from past elections. There is evidence of some confusion about the nature of the race. For example, Roderick Kiewiet and Michael Alvarez, who conducted telephone surveys of voters, found that over $6 \%$ of Davis supporters intended to vote "yes" on the recall-a vote clearly contrary to their preferences. These voters were less educated in general than other voters, suggesting that they were less likely to understand the unusual format. ${ }^{62}$ Another study by these authors and others also suggests that other voting mistakes occurred because the obscure candidates whose names appeared either immediately above or immediately below the names of Schwarzenegger, Bustamante, or McClintock picked up more votes than would have been predicted. Presumably, most of these votes were mistakes. ${ }^{63}$ Furthermore, subsequent studies have suggested that the use of punch card ballots led to significantly more undervoting than occurred in precincts using different technology. ${ }^{64}$ The under-

${ }^{61}$ See Jon A. Krosnick et al., An Unrecognized Need for Ballot Reform: The Effects of Candidate Name Order on Election Outcomes, in RETHINKING THE VotE: THE POLITICS AND Prospects of American Election Reform 51, 68 (Ann N. Crigler et al. eds., 2004) (providing evidence that "there is more than a slim chance that name order could affect the outcome of a close election," thus advocating that states "assign positions to all candidates equally often across precincts”); see also Daniel E. Ho \& Kosuke Imai, Randomization Inference with Natural Experiments: An Analysis of Ballot Effects in the 2003 California Recall Election 20 (Sept. 1, 2004) (unpublished manuscript, on file with author) (finding that candidates gained votes when they were listed on the first page of the ballot).

${ }^{62}$ D. Roderick Kiewiet, Comments at the Post-Mortem Conference on the Recall at USC Law School (Nov. 14, 2003) (student notes available at http://lawweb.usc.edu/ cslp/conferences/post-mortem_recall_03.html (last visited Sept. 20, 2004)) (from work with Michael Alvarez and forthcoming as a book); see also R. Michael Alvarez et al., The Complexity of the California Recall Election, 37 PS: POL. SCI. \& POL. 23, 24 (2004) (discussing a study of the various election day problems surrounding the California recall).

${ }^{63}$ Alvarez et al., supra note 62, at 24-25 (discussing ballot design and the "vertical proximity" phenomenon).

${ }^{64}$ See generally Michael P. McDonald, California Recall Voting: Nuggets of California Gold for Voting Behavior, FORUM, Vol. 1, Issue 4, Art. 6 (2003) (analyzing voter participa- 
vote was not significant enough to cast the results of the election into doubt because the recall and Schwarzenegger both won so decisively.

Notwithstanding these problems, none of which was substantial enough to affect the outcome of the election, the recall experience suggests that most voters are able to cope with some complexity in ballots. They can handle a ballot with more than two candidates for each office-and perhaps with significantly more than two candidates. Alvarez and Kiewiet's study, which focused on the choice among Davis, Schwarzenegger, Bustamante, and McClintock, supports the conclusion that voters cast their ballots in ways that were consistent with their preferences. Moreover, even though the multicandidate ballot raised the specter of vote cycling or other irrationalities of voting, the study demonstrates that the Condorcet winner in all pair-wise contests-Schwarzenegger-won the plurality voting as well. $^{65}$ That was not an inevitable result, and Kiewiet's discussion sets out ways that an irrational result could have emerged under the recall format, but it is a heartening result all the same. ${ }^{66}$ At the least, state officials relying on voter confusion to support stringent regulation of ballot access ought to be required to provide more than mere assertions in the political and judicial arenas. Courts should be more skeptical of these claims and understand that they are likely to be superficially neutral rationales offered for regulations designed to protect the two major parties and to lock out new voices. ${ }^{67}$ The recall election should also encourage reformers to seek greater ballot access in traditional candidate elections for independent and third-party candidates. If voters can handle a somewhat more complicated ballot, then much of the state's rationale for severely restricting ballot access has been undermined. Given the hostility of major-party officials to broader ballot access, reformers may need to turn to the initiative process to effect such changes.

tion in the recall election), available at http://www.bepress.com/forum/vol1/iss4/art6 (last visited Sept. 20, 2004).

${ }^{65}$ Kiewiet, supra note 62.

${ }^{66}$ The study by Alvarez et al. identified other problems with the election, including confusion because polling places were consolidated or moved and because of multilingual voting problems. Alvarez et al., supra note 62, at 23-24.

${ }^{67}$ I have argued elsewhere that courts should decline to become involved in many of these cases, regardless of the state interest. See Elizabeth Garrett, Is the Party Over? Courts and the Political Process, 2002 SUP. CT. REV. 95 (2003) (describing the jurisprudence of the political process as "inconsistent and unsatisfying"). However, if they do not adopt a policy of restraint, courts should be less willing to accept without proof empirical claims of state actors. See Samuel Issacharoff \& Richard H. Pildes, Politics as Markets: Partisan Lockups of the Democratic Process, 50 STAN. L. REV. 643 (1998) (describing various features of election law as the result of partisan lockups). 
Although many of the 135 candidacies were frivolous, the California recall campaign was unusual because several serious minor-party and independent candidates were relatively high-profile and participated in a series of statewide debates. In addition to two Republicans, Tom McClintock and Arnold Schwarzenegger, and Democrat Cruz Bustamante, independent candidates Arianna Huffington and Peter Ueberroth and Green Party candidate Peter Camejo received relatively extensive media coverage. Huffington benefited from her celebrity as an author, talk-show regular, and former wife of a wealthy politician. Ueberroth was a minor celebrity as former baseball commissioner, and he also spent some of his own fortune to gain media attention. Camejo was able to garner sufficient support in the polls to be included in televised debates. Inclusion of minor-party candidates and independents in a widely televised debate with all the major candidates is unusual in California. ${ }^{68}$

The debate that included all six candidates did not support the notion that multicandidate debates are appreciably more confusing or chaotic than debates with only the two major candidates. ${ }^{69}$ Just as Ross Perot's inclusion in the 1992 presidential debates focused attention on issues that the major-party candidates hoped to avoid, such as the federal budget deficit, the participation of candidates other than the two leading contenders in gubernatorial debates altered the topics covered and the arguments made. For example, Huffington, although generally clownish and extreme, challenged Bustamante on the contributions to his campaign by Indian tribes in a way that increased the salience of the issue. Camejo and McClintock presented the most detailed substantive proposals of all the candidates, providing voters a range of policies to consider and providing a sharp contrast to the virtually policy-free presentation of Schwarzenegger. The debate was not a model of rational argumentation, of course, but it was no worse than many less crowded ones, and any absurdities could be attributed as often to the major candidates as to the minor-party and independent

${ }^{68}$ See Lee Romney, Green Party's Man Is Tickled Pink over Debate, L.A. Times, Sept. 5, 2003, at A26 (noting that this was "the first time a Green Party candidate-or any thirdparty contender-had participated in a widely televised gubernatorial debate"); see also George Skelton, California Metro, Refreshing Gubernatorial Debate Is a Break from Usual Hot Air, L.A. Times, Sept. 19, 2002, at 8, available at LexisNexis, All News Library (noting that non-televised debate in 2002 election which included Camejo did not include Davis and garnered an audience of 100 and five television news crews).

${ }^{69}$ See Ark. Educ. Television Comm'n v. Forbes, 523 U.S. 666, 683 (1998) (accepting similar arguments to allow a state actor to limit political debates to two major candidates); see also Jamin B. Raskin, The Debate Gerrymander, 77 TEX. L. REV. 1943, 1948-68 (1999) (critiquing the Forbes case). 
candidates. Many Californians indicated that the televised debate in which Schwarzenegger, Bustamante, McClintock, Camejo, and Huffington participated was valuable in making up their minds at the polls. $^{70}$

Although none of the independents nor the Green Party candidate had a chance of being elected, winning elections is not the role of minor parties in the American political system. As Justice Thurgood Marshall observed in his dissent in Munro v. Socialist Workers Party, " $[\mathrm{t}]$ he minor party's often unconventional positions broaden political debate, expand the range of issues with which the electorate is concerned, and influence the positions of the majority, in some instances ultimately becoming majority positions." ${ }^{, 11}$ To play this role in public debate, however, minor parties and independent candidates need press coverage. In this election, celebrity ensured media attention for some candidates, such as Huffington. But for others, like Camejo, the ability to qualify for ballot access relatively easily and inclusion in widely televised debates allowed them to put forward new ideas and to challenge the traditional positions of the major party candidates.

Even though vast confusion did not result, California statutes should be amended to establish a clear process for access to the second part of the recall ballot. California avoided some of the pitfalls possible under the current recall format because of the decisive victories for pro-recall forces and for Schwarzenegger. A notinsignificant number of signatures should be required for ballot access, although the threshold must be realistic in the context of a condensed campaign period. The old constitutional standard- $-1 \%$ of those who voted in the last election-would now require more than 75,000 signatures, ${ }^{72}$ too onerous for candidates who would need to qualify quickly. Half that number of signatures would be a more reasonable threshold to discourage frivolous candidacies but still allow the possibility of access for serious minor party and independent candidates.

\footnotetext{
${ }^{70}$ Richard L. Hasen, Learning from the California Recall Experience, FindLaw's Legal Commentary, at http://writ.news.findlaw.com/commentary/20031013_hasen.html (Oct. 13, 2003).

${ }^{71}$ Munro v. Socialist Workers Party, 479 U.S. 189, 200 (1986) (Marshall, J., dissenting).

72 See CAL. SEC'y of STATe, Voter Participation Statistics by County, at http://www.ss.ca.gov/elections/sov/2002_general/contents.htm (last visited Sept. 20, 2004) (showing that more than 7.7 million individuals voted in the 2002 California general election).
} 
Some reformers have suggested eliminating the election for a successor and allowing the Lieutenant Governor to take over if the governor is recalled. ${ }^{73}$ This reform is problematic and, not surprisingly, often supported by those generally hostile to direct democracy. Because the Governor and Lieutenant Governor are elected separately in California and can be from different parties, such a reform could encourage the Lieutenant Governor's party to mount a recall drive and might erode any possibility of cooperation between the two officials. When the two top officers are from the same party, the voter disgust that leads to a recall is likely to be targeted at the administration, and the recall should provide an opportunity to begin governing with a clean slate. Moreover, if the recall stems from popular belief that the incumbent leaders are too attentive to powerful economic or other special interests, voters may want the opportunity to elect an outsider, as they did in 2003. For these reasons, most states that allow gubernatorial recalls also provide for an election of a successor, not the automatic elevation of the second-in-command. On the other hand, the independence of the elections of the two top state officers and the possibility that they will be from different parties might support a reform that allows the Lieutenant Governor to move up after a successful recall. Her administration is more likely to break from the policies of the previous governor, which is the point of a recall. On balance, however, this proposal has more drawbacks than promise, in my view, and is very unlikely to win the voter approval necessary to change the constitution.

In addition to clarifying the ballot access provisions, consideration should be given to adopting some sort of runoff system to ensure that a successor is not elected with a very small plurality-perhaps with fewer votes than those voting against the recall. That possibility, which did not occur in 2003 because Schwarzenegger's popularity provided him a substantial victory and more votes than the "no" votes on the recall, could undermine the legitimacy of the successor's administration. Even though a "no" vote on recall is not the equivalent of a vote for the incumbent-after all, some who vote "no" may just be opposed to a recall without having much enthusiasm for the current occupant of the office-it could be difficult for a newcomer to govern after a narrow plurality win. Some commentators have suggested that an instant runoff process could allow a decision to be made with one elec-

\footnotetext{
${ }^{73}$ E.g., Mark Ridley-Thomas \& Erwin Chemerinsky, Commentary, Now that It's Finally Over, Let's Revamp the Recall, L.A. TIMES, Oct. 29, 2003, at B15.
} 
tion. $^{74}$ Alternatively, a traditional runoff held shortly after the recall election would not be terribly disruptive because the recalled governor would remain in office in the interim. As the California experience demonstrates, the state continues to function without serious problems during the lame-duck period.

Some attention must be paid, however, to the need to resolve the recall and return to normal governance relatively quickly. Accordingly, a proposed reform to elect the successor to the recalled official in a separate election ${ }^{75}$ held some time after the recall is problematic because it lengthens any intermediate period when either a recalled governor remains in power or a Lieutenant Governor runs a caretaker administration, while likely also running for the top position permanently. Those who support separating the two parts of the election note that it would make the campaign fairer for the political party of the targeted incumbent. ${ }^{76}$ Under the current system, party leaders have a difficult message to sell to voters: do not vote for the recall because the governor is a strong leader who should be retained, but also vote in favor of a different copartisan to succeed him should the recall succeed. This mixed message may confuse voters, or strike a false note with them, and thus harm both the effort to retain the incumbent and the campaign for the strongest copartisan. ${ }^{77}$ Holding two different elections, with the possibility of a third election should a runoff be allowed, has its drawbacks, however. The period between a recall and successor election would necessarily be longer to allow a full campaign than the period between a combined election and any nec-

${ }^{74}$ See, e.g., Vikram David Amar, Governor Davis's Claim to Run as His Own Successor Is Meritless, but the Fear of a "Fringe" Winner Is Serious: How the Risk Can Be Eliminated in the Future, at http://writ.news.findlaw.com/amar/20030808.html (Aug. 8, 2003) (proposing that "Single Transferable Voting" be used to allow instant election runoffs).

${ }^{75}$ For example, three of four panelists on legal and constitutional changes in the wake of the recall favored such a reform. M. Dane Waters, Pamela Karlan \& Fredric Woocher, Comments at the Post-Mortem Conference on the Recall at USC Law School (Nov. 14, 2003) (student notes available at http://lawweb.usc.edu/cslp/conferences/ post-mortem_recall_03.html (last visited Sept. 20, 2004)). Eight states allowing recalls have a second election to replace any recalled official, whereas six hold simultaneous elections. Recall of State Officials, Nat'l Conference of State Legislators (June 23, 2004), at tbl. 2, at http://www.ncsl.org/programs/legman/elect/recallprovision.htm.

${ }^{76}$ See Pamela Karlan, Comments at the Post-Mortem Conference on the Recall at USC Law School (Nov. 14, 2003) (student notes available at http://lawweb.usc.edu/ cslp/conferences/post-mortem_recall_03.html (last visited Sept. 20, 2004)) (stating several problems associated with voting on the recall and for a successor simultaneously).

${ }^{77}$ See Bowler \& Cain, supra note 4, at 8 (citing several decisionmaking complexities for voters where a majority recall vote and a simple plurality replacement vote have been implemented). 
essary runoff. The proposal to separate the two decisions is also unattractive because a voter's decision whether to recall the governor is necessarily dependent on who is likely to succeed the incumbent. Structuring a process so that voters cannot be sure who will be running to replace the recalled official denies voters important information when they make the initial decision on the recall.

My preference is for a simultaneous election of a successor at the time of the recall vote, with serious consideration given to an instant runoff to quickly resolve any close plurality vote. Moreover, although states differ on this issue, it is sensible to prohibit the incumbent target of the recall from running to succeed himself; after all, if he is recalled, he has received a resounding vote of no confidence. Disallowing his candidacy in the successor election may mean that a recalled official in the last term of a term-limited office may never be able to run for that office again. In California, for example, the constitutional term limitation would preclude Gray Davis from running again for governor because if he won, he would serve more than two terms-in this case, about a year more than two terms. ${ }^{78}$ Where term limits do not apply, a recalled official should be able to run in elections after the replacement election and to convince voters that he has learned from his mistakes or that they were wrong to throw him out.

The recall election was notable for more than the sheer number of candidates; the structure, which dispensed with party primaries and allowed candidates direct access to the general election ballot, meant that voters could choose among different kinds of candidates. In traditional elections, Californians nominate party candidates for the general election through partially closed party primaries in which only registered party members and independents are allowed to vote. Access to the primary ballot is relatively easy and is not controlled by the party, which may endorse one of the candidates but cannot block ballot access. However, the semi-closed primary format means that motivated party activists who tend to vote disproportionately in such elections exert substantial influence over who appears on the general election ballot. A candidate like Schwarzenegger would have faced significant hurdles to winning the party primary because committed Republican activists find many of his positions on social issues distasteful and doubt his commitment to fiscal conservatism. ${ }^{79}$ Schwarzenegger

${ }^{78}$ See Schweisinger v. Jones, 81 Cal. Rptr. 2d 183, 189 (Ct. App. 1998) (ruling that a recalled state assembly member is prohibited from running again for the assembly because if she were elected, she would serve more than the constitutional limit of three terms).

${ }^{79}$ See Ronald Brownstein, No Matter Who Wins, Californians Can Expect More Turmoil, 
ran as a relatively moderate candidate, publicly relying on a bipartisan group of advisers and underscoring his relatively liberal positions on abortion and gay rights, while also seeking to establish his antitax credentials. Richard Riordan, a candidate with similar policy positions (although with substantially more political experience), was defeated in the 2002 Republican primary by a much more conservative Bill Simon. ${ }^{80}$ Although candidates like Simon may move slightly to the center in the final campaign, their public positions during the primary undermine the credibility of those moves.

Disappointed with their choices in general elections, a majority of voters in California adopted a blanket primary system in $1996 .{ }^{81} \mathrm{~A}$ blanket primary format, in which voters can vote in different party primaries for different offices, is likely to result in the election of candidates who appeal more to the median voter than to activists. Blanket primaries are moderating devices designed to move political parties closer to the center. In the words of a California ballot pamphlet, blanket primaries are intended to “weaken' party 'hard-liners' and ease the way for 'moderate problem-solvers' . ..." Blanket primaries, like other reforms supported by California voters such as term limits, may be a response to the perception that the candidates produced by the current system, and the officials elected through it, do not sufficiently share the values and views of the electorate. In other words, recent political developments in California, including the recall and the simultaneous election of a relatively moderate Republican, may be aspects of a larger effort to reduce the principal-agent slack between representatives and the represented, ${ }^{83}$ and to empower the median

L.A. Times, Oct. 6, 2003, at A10 (noting that in California, "Republican candidates with views on social issues... liberal enough to win a general election usually have been unable to survive a primary process dominated by conservatives").

${ }^{80}$ CAl. Sec'y of State, Statement of Vote: 2002 Primary Election, at xxiii (2002), available at http://www.ss.ca.gov/elections/sov/2002_primary/contents.htm (last visited Sept. 20, 2004). See generally Miguel Bustillo, California Metro, GOP Candidates Face Uphill Battle for Statewide Offices, L.A. Times, Mar. 25, 2002, at 1 (noting that Simon was "more conservative" than the "moderate" Riordan).

${ }^{81}$ Proposition 198, the "Open Primary" initiative, passed with $60 \%$ of the vote. Cal. Online Voter Guide, 1996 California Primary Election Results, at http://www.calvoter.org/voter/elections/archive/96pri/results.html (last visited Sept. 20, 2004).

${ }^{82}$ Cal. Democratic Party v. Jones, 530 U.S. 567, 570 (2000) (quoting the California ballot pamphlet).

${ }^{83}$ For discussions of the principal-agent slack and institutional features of the political system that cause and exacerbate the problem, see Samuel Issacharoff \& Daniel R. Ortiz, Governing Through Intermediaries, 85 VA. L. REV. 1627 (1999); Daniel R. Ortiz, Duopoly Versus Autonomy: How the Two-Party System Harms the Major Parties, 100 Colum. L. REV. 753 (2000). 
voter. $^{84}$ Unfortunately for voters trying to use the blanket primary to change the kind of candidates they can vote for in a general election, the Supreme Court struck down the primary on the ground that it impermissibly infringed on the First Amendment rights of party members. ${ }^{85}$ This holding has led to the invalidation of blanket primary systems in Washington and Alaska, ${ }^{86}$ states where the blanket primary had long been used and, at least in the case of Washington, had not significantly weakened political parties. ${ }^{87}$

Jones prohibits the people or legislatures from imposing blanket primaries on political parties; it does not prohibit the parties themselves from adopting different primary systems. In the wake of Jones, the major parties in California opened their party primaries to independents, although they did not go so far as to allow open primaries. To respond to voters' preferences demonstrated by the recall and the enactment of the blanket primary, party leaders should restructure their primary rules so that they shift power to the median voter and away from the party activist. Parties would not be helpless under such a system. Through endorsements, recruitment efforts, campaign spending, and assistance, parties can influence the outcomes of more open primaries.

However, the major political parties in California continue to ignore the dissatisfaction of voters with the choices that emerge from the current structure of primary elections. In November 2004, Californians will vote on an initiative that would require all state and federal elections, except for the presidential election, to be nonpartisan, ${ }^{88}$ an option that the Court in Jones left open as a constitutionally permis-

${ }^{84}$ See Samuel Issacharoff, Collateral Damage: The Endangered Center in American Politics, 46 WM. \& MARY L. REV. (forthcoming Nov. 2004) (Feb. 4, 2004 draft at 2, available at http://ssrn.com/abstract=508584 (last visited Sept. 20, 2004)) (characterizing blanket primary and California recall as part of a "rebellion of the median voter").

${ }^{85}$ See Jones, 530 U.S. at 586 (holding open primaries unconstitutional since they force "political parties to associate with those who do not share their beliefs").

${ }^{86}$ Democratic Party of Wash. State v. Reed, 343 F.3d 1198 (9th Cir. 2003); O'Callaghan v Kowalski, 6 P.3d 728 (Alaska 2000). I have criticized the Court's decision in Jones in Garrett, supra note 67, at 126-30.

${ }^{87}$ See Richard L. Hasen, Do the Parties or the People Own the Electoral Process?, 149 U. PA. L. REV. 815, 834 (2001) ("Despite the existence of the blanket primary in the State of Washington for many years, the Republican Party there is among the strongest party organizations in the nation.").

${ }^{88}$ Proposition 62, Voter Choice Open Primary Act, available at http://www.ss.ca.gov/elections/elections_viguide_pg04.htm (last visited Sept. 20, 2004); see also Richard J. Riordan, Opinion, Set the Voters Free, N.Y. TimEs, Oct. 31, 2003, at A23 (advocating nonpartisan elections in New York City and California). 
sible reform. ${ }^{89}$ Rather than responding pragmatically by further opening their primary selection process, the parties are obstinately fighting to retain the status quo. The legislature placed a competing question on the November ballot requiring partisan primaries, ${ }^{90}$ as well as actively opposing the nonpartisan primary initiative. ${ }^{91}$

The preference for more open candidate selection processes that favor moderates is only one of the various messages of the recall election with broader application to California and the nation. The strong anti-incumbent tone in exit interviews with voters, as well as surprising voting behavior by certain ethnic and other demographic groups, have no doubt provided strategists food for thought as they look toward the 2004 presidential election and the next statewide election in California. For example, women and Hispanic voters supported both the recall and Schwarzenegger in much larger numbers than had been predicted. ${ }^{92}$ The lukewarm support Hispanic voters provided Bustamante, the Hispanic Democratic candidate, was a surprise, and one that both major parties will assess in future months. ${ }^{93}$

\section{LAWSUITS AS POLITICAL WEAPONS}

The short campaign period was nonetheless long enough for more than fifteen lawsuits to be filed in federal and state courts. ${ }^{94} \mathrm{Had}$ the election been closer, more lawsuits would likely have been filed in

89 See Jones, 530 U.S. at 585-86 (noting that a "nonpartisan blanket primary"which would "ensure more choice, greater participation, increased 'privacy,' and a sense of 'fairness" - would not infringe on a party's constitutional right of association).

${ }^{90}$ Proposition 60, Proposed Amendment to Article II, available at http://www.ss.ca.gov/elections/elections_viguide_pg04.htm (last visited Sept. 20, 2004).

91 See Christian Berthelsen, Senate Elections Bill Undermines Open Primary Ballot Initiative, S.F. Chron., June 22, 2004, at B3 (reporting that the legislature's proposed amendment "enjoyed a wide margin of bipartisan support").

${ }^{92}$ See Matt A. Barreto \& Ricardo Ramirez, Minority Participation and the California Recall: Latino, Black, and Asian Voting Trends, 1990-2003, 37 PS: PoL. ScI. \& PoL. 11, 13 (2004) (observing that Bustamante "received significantly lower than execpected levels of [Democratic] support"); The Recall Election: Times'Exit Poll Results, L.A. TiMES, Oct. 9, 2003, at A26 (breaking down the election results by demographics).

93 See Jonathan Nagler \& R. Michael Alvarez, Latinos, Anglos, Voters, Candidates, and Voting Rights, 153 U. PA. L. REV. 393, 430 (2004) (noting that "a strong 44\% of Latino voters did not support Bustamante, with $41 \%$ of Latino voters supporting one of two Anglo Republican candidates").

${ }^{94}$ See Karen Getman, Recall Litigation, Update (Oct. 17, 2003) (on file with the University of Pennsylvania Law Review) (prepared for the Gubernatorial Recall Process Forum at USC (Oct. 21, 2003)) (detailing the issues and status of all recall cases). 
its aftermath. Election-related lawsuits are not a new phenomenon, ${ }^{95}$ particularly in the context of direct democracy where federal and state courts have invalidated initiatives or ruled that they cannot appear on the ballot. The litigation in the California recall, however, seems quantitatively and qualitatively different from what we have previously witnessed. Moreover, the amount of media attention focused on the lawsuits appears greater, transforming litigation into a method to make issues salient for journalists and voters. These two changes feed on each other as the media attention encourages more filings and as more filings catch the attention of journalists. Some of the recall cases were entirely driven by political considerations, such as the early lawsuit $^{96}$ attacking the qualifications of the petition circulators mostly on grounds rejected by Supreme Court precedent in the context of initiatives and likely applicable to recalls. The main purpose of the lawsuit was not to succeed in court, but rather to frame the recall effort as controlled by out-of-state wealthy interests and thus not a true California grassroots movement. The media is now particularly focused on election-related lawsuits after Bush v. Gore, so a court battle was an effective way to make the nature of the petition drive apparent to potential voters.

One puzzle in politics is why a particular process that has been available to strategic actors in the past suddenly becomes a more important tool in their arsenal. For example, initiatives were used extensively in the early part of the twentieth century, and then fell into disuse, only to reemerge as a potent political force after the success of California Proposition 13 in $1978 .{ }^{97}$ In part, the rejuvenation of direct democracy occurred because a political entrepreneur "discovered" the potential of the largely moribund process. His success inspired others to follow his lead, spawning an industry that fostered further use of initiatives. ${ }^{98}$ The catalyst for the aggressive use of lawsuits as a political

\footnotetext{
95 See generally SAmuel ISSACHAROfF ET AL., When Elections Go BAD: THE LAW OF DEMOCRACY AND THE PRESIDENTIAL Election OF 2000 (2001) (providing an analysis and discussion of such cases as well as the lawsuits surrounding the 2000 presidential election).

${ }^{96}$ Robins v. Shelley, No. BC299066 (Cal. Super. Ct. filed July 15, 2003) (dismissed after the issue became moot) (complaint available at http://news.lp.findlaw.com/ hdocs/docs/elections/robinsvshelley071503cmp.pdf (last visited Sept. 20, 2004)).

97 See DAVid B. Magleby, Direct Legislation: Voting on Ballot Propositions IN THE UNITED STATES 5-7 (1984) (discussing the rise and fall and second rise of initiatives); Daniel A. Smith, Tax Crusaders and the Politics of Direct Democracy 5284 (1998) (discussing the role of Proposition 13 in rejuvenating direct democracy).

${ }^{98}$ A similar "discovery" led to the widespread use of soft money in federal campaigns. This election law loophole was not new when it was first used in unprecedented ways by Democrats in 1996. See Anthony Corrado, Party Soft Money, in
} 
strategy in the recall election was the litigation surrounding the 2000 presidential election, which successfully aborted the political process and ensured a Bush victory.

Even without Bush v. Gore, some litigation probably would have occurred during or after the recall campaign for several reasons: the unusual nature of a statewide recall election, the shortened campaign period and its interaction with a planned change in voting technology effective March 2004, and problems inherent in poorly drafted and little-used election laws. However, Bush v. Gore also played a vital role. Justice Ruth Bader Ginsburg's prediction that Bush v. Gore was a "one of a kind case" ${ }^{\text {"99 }}$ was premature (or perhaps wishful thinking). Although the Supreme Court may never cite it as "precedent . . . on anything," 100 as Ginsburg forecast, the case taught political strategists that the courts are yet another battleground in a campaign. That lesson was extended in the recall as strategists demonstrated that the judicial fight need not wait until after votes have been cast. Indeed, recourse to the courts may serve its political purposes best if a lawsuit is brought during the campaign when it can affect voter turnout and how votes are cast.

Although plaintiffs challenging aspects of the petition drive, campaign, or election were successful in only one of the cases, ${ }^{101}$ the lawsuits affected the recall in significant ways. The most potentially dis-

CAMPAIGN FinANCE REFORM: A SOURCEBOOK 167, 167-68 (Anthony Corrado et al. eds., 1997) (noting that the ability of parties to collect soft money contributions had existed since the amendment of the Federal Election Campaign Act in 1974); Diana Dwyre \& Robin Kolodny, National Political Parties After BCRA, in LIFE AFTER REFORM: WHEN THE Bipartisan CAMPaign Reform Act Meets Politics 83, 89-90 (Michael J. Malbin ed., 2003) (noting that political parties "figured out how to fully take advantage of the soft money-issue advocacy 'loophole'" in 1996). This loophole with respect to party soft money has apparently been closed by BCRA, and the Supreme Court upheld these provisions in McConnell v. FEC.

${ }_{99}$ See Charles Lane, One More Round for Bush v. Gore, WASH. POST, Sept. 16, 2003, at A1 (reporting Justice Ginsburg's doubts that Bush v. Gore will ever be useful precedent).

${ }^{100}$ Id. Other courts, however, likely will use it as precedent. See, e.g., Black v. McGuffage, 209 F. Supp. 2d 889, 898-99 (N.D. Ill. 2002) (applying Bush v. Gore in denying defendants' motion to dismiss in a lawsuit challenging punch card voting machines as violating equal protection). And a panel of the Ninth Circuit would have delayed the recall election using Bush v. Gore as precedent had the decision not been overruled by the en banc panel. See Southwest Voter Registration Educ. Project v. Shelley, 344 F.3d 882, 895 (9th Cir.) (en banc) (per curiam), vacated by 344 F.3d 914 (9th Cir. 2003) (en banc).

${ }^{101}$ See Partnoy v. Shelley, 277 F. Supp. 2d 1064 (S.D. Cal. 2003) (ruling that Californians could vote in the election for governor even if they did not vote on the recall itself and holding unconstitutional the statute that required a vote in the recall as a condition to vote for a successor). 
ruptive lawsuit, the challenge to the punch card voting machines used in the most populous counties in the state, occurred at the end of the period to register to vote and at a time when many absentee ballots were being cast. The three-judge appellate panel rendered an opinion a week before the deadline for voter registration; had this opinion gone into effect, the election would have been delayed, perhaps until March. ${ }^{102}$ The en banc panel did not reverse the decision until the day after the deadline for registration had passed. Some who might have registered to vote may have been discouraged from doing so because they thought the election had been postponed. Although registration for the recall was substantial, the uncertainty caused by the litigation likely deterred some potential registrants.

Lowenstein has argued that the opinion, even though superseded, caused other mischief, including disrupting candidates' fundraising and other strategic planning, as well as diverting voters' attention away from the election. ${ }^{103}$ These harms are overstated in this case. The period between the opinion of the three judges and the reversal by the en banc court was brief, so candidates probably did not substantially change their strategies or find their fundraising abilities impaired. Certainly, their campaigns would have been significantly disrupted had the election been postponed; fundraising and money-spending plans had been determined in light of the condensed campaign period. The fear that voters were sidetracked by the coverage of the lawsuit is also not convincing. The media attention on the opinions and the televised oral argument before the en banc court may well have heightened voter interest in the recall rather than diverted it.

Nonetheless, Lowenstein's larger point is valid. Had the election been postponed, election officials would have faced serious problems. With widespread use of absentee voting in California, hundreds of thousands of ballots had already been submitted. In modern elections, the actual process of voting now takes place over many dayssometimes weeks-so developments in the last days of a campaign can implicate the voting process itself. The Los Angeles County Registrar informed the en banc panel that she did not believe the unusual recall ballot could be accommodated in the March election that was scheduled to serve as a test of a new voting technology, the Inka-Vote sys-

${ }^{102}$ See Southwest Voter Registration Educ. Project, 344 F.3d at 895 (ordering on September 15, 2003 that " $[\mathrm{t}]$ he Secretary of State is enjoined from conducting an election on any issue on October 7, 2003"), vacated by 344 F.3d 914 (9th Cir. 2003) (en banc) (reversing the decision on September 23).

${ }^{103}$ Daniel H. Lowenstein, An Irresponsible Intrusion, Forum, Vol. 1, No. 4, Art. 4 (2003), at http://www.bepress.com/forum/vol1/iss4/art4 (last visited Sept. 20, 2004). 
tem. ${ }^{104}$ Not only is new technology prone to unexpected "bugs" when it is first implemented, but the InkaVote system has a limited capacity. ${ }^{105}$ The recall plus the regularly scheduled presidential primary would have resulted in a ballot too long for the system. ${ }^{106}$

Perhaps dealing with such logistical challenges is warranted in a few cases where an election is plagued by serious constitutional infirmities that cannot be remedied after the election. Suits brought under section 5 of the Voting Rights Act, which have occasionally delayed elections, are examples of such cases. Those who advocate judicial intervention tend to raise appalling hypotheticals where the state action described would egregiously deprive many voters of their right to cast a ballot that will be counted. Such a parade of horribles is a neat advocate's trick, but it is far removed from the reality of modern elections. The trend since Bush $v$. Gore is for political actors to use litigation as another tool to change the rules once the game has started by demanding something near to perfection from elections and those who run them. In many of these cases, lawsuits are brought opportunistically to force changes by judges who often do not have good information about the implications of any decision in the larger context of the election. For example, the three-judge panel did not have information about the logistical difficulties of a March election when it rendered its decision; instead, the arguments were presented in a letter from the Los Angeles County Registrar to the en banc panel. The price of judicial involvement is uncertainty and the specter of unfairness as political battles are fought in the courts.

One way to combat this new and more aggressive use of litigation as a political tool would be for the courts to refuse to entertain such suits in all but the most extreme cases. Although filing the suits would still result in some publicity and help frame political issues in ways that would help particular candidates, media and public attention would wane if courts backed out of the political realm and refused to follow the Supreme Court's example in the 2000 election. ${ }^{107}$ Unfortunately,

${ }^{104}$ Declaration of Conny B. McCormack at paras. 6-9, Southwest Voter Registration Educ. Project v. Shelley, 344 F.3d 914 (9th Cir. 2003) (en banc) (per curiam), available at http://news.lp.findlaw.com/hdocs/docs/elections/svrepvshlly91703ami.la.pdf (last visited Sept. 20, 2004).

${ }^{105} \mathrm{Id}$.

${ }^{106}$ See id. (noting that the regularly scheduled primary elections, coupled with the 135 candidates vying in the recall election, could not be accommodated by the InkaVote system).

${ }^{107}$ I have argued that court involvement in political party cases generally should be minimal, and the factors that militated in favor of judicial restraint there also apply in many of the campaign and election lawsuits. Garrett, supra note 67, at 143-48. 
many judges do not seem eager to exit from the political thicket, although it is noteworthy that only one of the plethora of recall cases succeeded in court (with some of the section 5 cases resulting in action by the Department of Justice). Perhaps reiteration of the strong presumption that courts should not intervene in elections would reverse the post-Bush $v$. Gore developments. ${ }^{108}$ Some firm statement by courts is necessary to convince political actors not to resort to lawsuits when it serves their political interests. Candidates will use lawsuits as long as there is a potential benefit of political and media exposure and very little risk of harm just as politicians have continued to file suits on internal congressional matters and interbranch disputes even though the D.C. Circuit and the Supreme Court have severely limited the possibility of success. ${ }^{109}$ But an inhospitable judicial doctrine would surely deter some of these cases, and the press would not be as interested in clear losers.

Other solutions that do not depend on the judiciary's commitment to passive virtues might offer more promise of reducing the number of election-related lawsuits. Often elections that are plagued by judicial challenges result in sweeping election law reform, ${ }^{110}$ and California should immediately embark on a project to clean up and modify its rules concerning recalls. Constitutional changes are difficult, so, for example, changing the threshold of signatures required to qualify a recall for the ballot may be difficult to achieve. However, the legislature has the power to amend the election laws, and it should begin to address issues raised by the many lawsuits. ${ }^{11}$

The legislature should consider whether it is appropriate to place on the recall ballot any initiatives that have qualified and are awaiting a vote. The en banc panel of the Ninth Circuit suggested strongly that the shortened recall campaign period was not conducive to thoughtful

${ }^{108}$ See Lowenstein, supra note 103, at 2 (supporting this presumption and arguing that "[i]n our republic, political controversies should be resolved through politics, not law suits").

109 See William N. Eskridge, JR., Philip P. Frickey \& Elizabeth Garrett, Cases AND Materials on Legislation: Statutes AND the Creation of Public Policy 44649 (3d ed. 2001) (discussing the relevant cases in which the D.C. Circuit used an equitable doctrine to avoid the merits of such cases and the Supreme Court limited congressional standing).

${ }^{110}$ See Bruce E. Cain, Flaws Everywhere: A Review of a Badly Flawed Election, 2 ELECTION L.J. 525, 526-27 (2003) (book review) (discussing such state and federal reform efforts after the 2000 presidential mess).

111 See Vikram David Amar, Adventures in Direct Democracy: Constitutional Lessons from the California Recall Experience, 92 CAL. L. REv. 927, 931-32 (2004) (listing various problems in the California election laws relating to recalls). 
consideration of other ballot questions. ${ }^{112}$ The laws governing statewide recall elections must be rewritten to eliminate problems like the failure to provide workable ballot access regulations. The campaign period should be reassessed and perhaps extended slightly to account for the logistics of holding a statewide election with tens of thousands of polling places. Other issues that could have given rise to litigation but did not should nevertheless be addressed. Thought should be given to what would happen if a governor resigned before the election but after the petitions were verified by the Secretary of State. ${ }^{113}$ Some registrars permitted overseas absentee ballots to be faxed, which raised the question of whether faxed ballots violate the requirement of a secret ballot. ${ }^{114}$

As reforms are debated, drafters must work to avoid adopting changes that actually increase the opportunity for judicial involvement in the political realm. One proposal that has been discussed would amend the constitutional recall provisions to set forth only certain grounds that could support a recall. ${ }^{115}$ Currently, the California Constitution requires groups seeking a recall to provide reasons and to include those reasons on the petitions that they circulate. ${ }^{116}$ The explanation for the recall is provided to voters in the Official Voter Information Guide. Unlike impeachment, ${ }^{117}$ the state's recall provisions do not specify particular grounds that may sustain a recall. In my

112 See Southwest Voter Regis. Educ. Project v. Shelley, 344 F.3d at 914, 919 (9th Cir.) (en banc) (per curiam) (refusing to delay voting on ballot initiatives attached to the recall election even while finding less chance of material harm in delay because all parties involved expected the election to take place later, when the initiatives were certified, and because they would not be put into effect right away), vacated by, reh'g, en banc, granted by 344 F.3d 914 (9th Cir. 2003).

${ }^{113}$ See Nathan C. Masters, Davis Resignation Scenario Murky, Experts Say, Cybercast News Service, at http://www.cnsnews.com/Politics/Archive/200308/POL20030813c.html (Aug. 13, 2003) (describing the uncertainty under the law and disagreement by experts on what would be done following a resignation); see also Woocher, supra note 51 (arguing that, if a governor resigns before the recall election, the election should not proceed, as it would essentially be a recall of the lieutenant governor).

114 See Sandy Kleffman \& Dogen Hannah, Legality of Faxing Ballots Adds to Confusion, CONTRA COSTA Times, Sept. 12, 2003, at A23 (highlighting legal concerns raised by accepting faxed ballots).

${ }_{15}$ Amar, supra note 111, at 931-32 ("As another option, the recall provisions of the California constitution could provide for a substantive standard identifying only certain grounds on which a recall may be based, in the way that the California and federal constitutions do for the impeachment of officers." (footnote omitted)).

${ }^{116}$ CAL. CONST. art. II, § 14(a).

${ }^{117}$ CAL. CONST. art. IV, $\$ 18$ (b) (allowing impeachment of state elected officials for "misconduct in office" and referring to the possibility in some cases of criminal punishment as well). 
view, that constitutional silence is appropriate. Recall is aimed at removing officials who have acted "corruptly" in the sense that they are no longer representing the people but are serving the interests of a powerful minority. This kind of "corruption" is very difficult to define or specify; it is something more ineffable than bribery or outright conflict of interest. It is the kind of concern that motivates campaign finance reform efforts, lobbying reform, and other "good government" initiatives. The protection against the inappropriate use of recall is not through additional substantive standards that attempt to define something that is context-specific and hard to precisely delineate. The protection should be procedural. This is the same sort of protection provided by the federal Constitution in the case of expelling a member of Congress. ${ }^{118}$ The state constitution provides no substantive criteria for the legislature, but protects against misuse through supermajority voting requirements. Accordingly, constitutional reform of recall should target the signature threshold, but with the objectives of direct democracy in mind, and other procedural hurdles designed to ensure that there is widespread dissatisfaction with an official before she is recalled.

If drafters disagree, however, and include substantive grounds that are the sole grounds for a recall, ${ }^{119}$ they should be careful not to invite judicial meddling in the process. To be consistent with the purpose behind the recall, the criteria must include some notion of corruption or overcompliance with the wishes of powerful minority interests. To limit recall to misconduct in office amounting to or close to criminal behavior-the grounds that usually support impeachment-would unduly constrain the recall mechanism. The use of vague standards like "corruption," however, will invite judicial second-guessing, and any intervention is likely to be generally hostile toward recall efforts because judges are wary of direct democracy and of unusual political arrangements that seem chaotic or dangerous. ${ }^{120}$ Vikram Amar has proposed that the constitution specify the permissible bases for a recall because this reform "might make some would-be signers a bit more thoughtful," but he is careful to propose that the adequacy of

\footnotetext{
${ }^{118}$ U.S. CONST. art. I, $\S 5$.

119 Seven states that allow recall of statewide offices specify particular grounds. See NAT'L CONFERENCE OF STATE LEgISLATORS, supra note 75 (providing list of states and grounds for recall).

${ }^{120}$ See generally Richard H. Pildes, Democracy and Disorder, in THE Vote: Bush, GORE AND THE SUPREME COURT 140 (Cass R. Sunstein \& Richard A. Epstein eds., 2001) (discussing judicial distaste for unusual and more open political arrangements and institutions).
} 
the reasons given in a particular petition drive should be unreviewable by either the Secretary of State or the courts. ${ }^{121}$

Bush v. Gore did not invent election-related litigation. Close and contentious elections have spawned litigation in the past, although more frequently lawsuits are brought after, rather than before, the election. But the Supreme Court's unwise intervention into the 2000 presidential election legitimated a more activist judiciary in this arena. It demonstrated that judges could essentially decide an election without much harm to their reputation, ${ }^{122}$ and it taught wily political strategists a new trick. Not surprisingly, political actors are now pushing the boundaries, moving litigation earlier into the election process. It may be difficult to put this genie back in the bottle as long as there are at least some judges willing to entertain the cases and as long as the litigation garners media attention.

\section{THE INTERPLAY BETWEEN REPRESENTATIVE DEMOCRACY AND DIRECT DEMOCRACY}

The recall forcefully underscores the interaction between representative democracy and direct democracy. A recall is essentially a popular vote of no confidence in a public official that precipitates an electoral evaluation before the regularly scheduled vote. Cronin concludes his analysis of the recall by labeling it "a helpful yet crude safety valve at the state and community levels." ${ }^{123}$ Critics of the California recall decried it as undemocratic because it undermined an element of representative democracy, namely, regularly scheduled elections which allow for political accountability at regular periods but do not introduce the specter that one unpopular decision will result in backlash that can oust an official before the end of her term. Although this feature of representative democracy may have some advantages, it is not a necessary part of democratic institutions. Parliaments can be dissolved unexpectedly upon a vote of no confidence, for example. In California and some other states, constitutions set up a hybrid democratic system that has elements of representative democracy and elements of direct democracy. Critics may argue that California has the

${ }^{121}$ Amar, supra note 111, at 932 n.24. Currently, the sufficiency of the reasons provided by recall supporters is unreviewable. CAL. ConST. Art. II, § 14(a).

${ }^{122}$ See James L. Gibson et al., The Supreme Court and the US Presidential Election of 2000: Wounds, Self-Inflicted or Otherwise?, 33 BRIT. J. POL. SCI. 535, 543 (2003) (finding little diminution in the Supreme Court's legitimacy, even among African Americans, in the aftermath of Bush v. Gore).

${ }^{123}$ Cronin, supra note 3, at 156. 
balance wrong-with too much popular involvement and not enough leeway for representatives-but the elements of direct democracy are not "undemocratic." ${ }^{124}$ Rather than attacking problems by mislabeling them, commentators would do better to devise reforms to ensure that California's hybrid system leads to better governance. A hybrid system appropriately includes the possibility of recall as one way for voters to reduce the principal-agent slack that inevitably develops between voters and representatives, particularly when the latter are not termlimited.

This recall election underscored the relationship between the two parts of the state's hybrid system in several more subtle ways than its role as a popular device to remove a representative. First, the recall was possible in part because turnout for the 2002 gubernatorial election was so anemic that the threshold for ballot qualification was unusually low. Remember that the trigger for ballot access is tied to a percentage of those voting in the last election for the office. ${ }^{125}$ Thus, the public's lack of enthusiasm for the lackluster candidates in the previous regular election-Gray Davis and Bill Simon-resulted in a low turnout, which in turn made all of the tools of direct democracy easier to wield. Ironically, part of Gray Davis's strategy in the 2002 election was to depress voter turnout, setting the stage for his unprecedented ouster. Not only are initiatives and recalls formally less difficult to use when voter dissatisfaction yields low turnout, but voter disgust with politicians encourages groups seeking change to bypass the traditional legislative process.

Second, many have argued that the budget problems faced by California are caused in part by the frequent use of initiatives to commit budgetary resources to particular projects. The concern with the influence of initiatives on budget resources is that when lawmakers begin work on the state's annual budget, they find a tremendous amount of revenue has already been committed to particular projects and is not available for uses determined appropriate by lawmakers. For example, Proposition 98, passed in 1988, mandates that funding for education from kindergarten through community college at least equal the previous year's spending, adjusted for inflation and population growth. It also commits the state to spending half of any budget surplus on education, which then goes into the base for computing

${ }^{124}$ Cf. Dan M. Kahan, Democracy Schmemocracy, 20 CARDOzo L. REv. 795 (1999) (arguing that "democracy" has many different meanings and can be realized through different institutions).

${ }^{125}$ Supra note 5 and accompanying text. 
next year's financial commitment. ${ }^{126}$ Under Proposition 98's terms, about $\$ 30$ billion of the state's budget currently must be spent on education from kindergarten through community college. ${ }^{127}$ Other propositions may indirectly claim a share of the state's resources. Proposition 184, the nation's toughest three-strikes law, would seem to require significant resources for prison construction and maintenance. When it was on the ballot, the legislative analyst estimated that Proposition 184 could cost the state up to $\$ 3$ billion annually in the short term and $\$ 6$ billion annually over the long term, plus $\$ 20$ billion in increased prison construction costs. ${ }^{128}$

The total amount of the budget earmarked each year by initiatives has become the subject of debate in California and elsewhere. ${ }^{129}$ Laura Tyson wrote that $70 \%$ of the state's budget has been earmarked by initiatives; she provided no support, however, for this figure. ${ }^{130} \mathrm{~A}$ study by John Matsusaka attempts to systematically test claims that the initiative process has effectively removed substantial portions of the state's budget from the control of legislative policymakers. He found that 32\%—not 70\%—of the state's total 2003-2004 budget of $\$ 101$ billion was earmarked by initiatives, and that most of the money was committed to education by Proposition $98 .^{131}$ He also discovered that

\footnotetext{
${ }^{126}$ Proposition 98, Classroom Instructional Improvement and Accountability Act, available at http://holmes.uchastings.edu/cgi-bin/starfinder/0?path=calprop.txt \&id=webber\&pass=webber\&OK=OK (last visited Sept. 20, 2004).

${ }^{127}$ See JOHN G. Matsusaka, HaVe Voter Initiatives Paralyzed the CAlifornia Budget? 5 (Nov. 2003) (USC-Caltech Center for the Study of Law and Politics, Working Paper No. 23) (listing quotations from pundits blaming initiatives for California's budget problems), available at http://lawweb.usc.edu/cslp/pages/papers.html (last visited Sept. 20, 2004).

${ }^{128}$ See CAL. ATtORney Gen., Official Title And Summary fOR Proposition 184 (1994) (providing summary of legislative analyst's estimate of net fiscal impact), available at http://holmes.uchastings.edu/cgi-bin/starfinder/0?path=calprop.txt\&id=webber \&pass=webber\&OK=OK (last visited Sept. 20, 2004); see also RAND CORP., CALIFORNIA's NeW ThreE-STRIKES LAW: Benefits, Costs, AND Alternatives (n.d.), at http://www.rand.org/publications/RB/RB4009/RB4009.word.html (last visited Sept. 20,2004 ) (estimating that the three-strikes law would cost between $\$ 4.5$ and 6.5 billion annually).

${ }^{129}$ For example, in recent hearings about the rules governing initiatives in Florida, one lawmaker warned against the "Californi-fication of Florida" and stated that California's budget deficit was largely caused by initiatives. Bill Cotterell, Petition Process Going Awry?, TALLAHASSEE DEMOCRAT, Dec. 9, 2003, available at http://www.kentucky.com/ $\mathrm{mld} /$ democrat/news/local/7447094.htm (last visited Sept. 20, 2004).

${ }^{130}$ Laura D'Andrea Tyson, A New Governor Won't Fix What Ails California, Bus. WK., Sept. 22, 2003, at 24

${ }^{131}$ MATSUSAKA, supra note 127, at 4-5. Legislative measures put on the ballot may contribute to the budget problem. For example, a proposition passed in 2002 required that some gasoline taxes be used only for transportation. Although the people
} 
some initiatives expected to cost the state significant money, such as the three-strikes law, have not yet affected the state's bottom line. ${ }^{132}$ Not only is the amount of "budget paralysis" caused by direct democracy overstated by Tyson and others, according to Matsusaka, but it seems likely that the state would spend money in ways mandated by initiatives even without the voter directive. Californians voted for Proposition 98 because they value education and want that to be reflected in the state's budget priorities; representatives are likely to spend a considerable portion of the state's revenues on education with or without Proposition 98. Of course, they might not have allocated about $30 \%$ of the budget to kindergarten through community college programs, and in cases of fiscal crisis, they might have been forced to make some reductions in those programs not allowed by Proposition 98's terms. However, even with Proposition 98, Schwarzenegger was able to negotiate a reduction in the mandated increase for one year. ${ }^{133}$ Matsusaka's study casts doubt on the claim that direct democracy has played the major role in budgetary crises, at least to the extent that the claim is based on earmarking. Matsusaka is clearly correct that the budget crisis is more a political crisis than the product of direct democracy: ${ }^{134}$ that is, elected officials do not want to face the hard choices of cutting popular programs, raising taxes, or both.

However, the influence of direct democracy on the state's economic and political environments is more extensive than that caused by ballot questions which earmark funds. In California, many of the structural hurdles that the legislature faces in raising revenue to meet budget shortfalls are the product of initiatives. Proposition 13 lowered property taxes and limited future increases, making localities more dependent on income and other tax revenues from the state. In

are involved in passing such initiatives, they are put before the people by the legislature; accordingly, any blame for these enactments should be shared by the legislators and voters. Matsusaka reviewed legislative initiatives passed since 1990 and preliminarily found that bond issues, the most fiscally significant of these ballot questions, earmark about $\$ 2.4$ billion for debt service. Id. at 7-8.

${ }^{132} I d$. app. at 10 (describing costs of Proposition 184 and noting that RAND revised its estimates after some experience with the three-strikes law).

${ }^{133}$ See Jennifer Coleman, School Deal Means Enough Money to Cover Higher Enrollment, Mercury News (San Jose), Jan. 8, 2004 (reporting that the deal reached meant that education got only $\$ 2$ million of the $\$ 4$ million required under the Proposition 98 formula, although the base for next year would include the full $\$ 4$ million), available at http://www.siliconvalley.com/mld/mercurynews/news/local/7665029.htm (last visited Sept. 20, 2004).

${ }^{134}$ See MATSUSAKA, supra note 127, at 8 (finding that the California budget has not been paralyzed by voter initiatives but by "the inability of elected officials to manage the competing demands for public funds in a period of declining revenues"). 
turn, the state has fewer resources to meet its own obligations. Voters also imposed a two-thirds supermajority voting requirement on the legislature for any tax increase.

Other problematic provisions in the state constitution are the product of legislatively initiated ballot measures. California has a twothirds supermajority voting requirement to pass the state budget, whether or not it increases taxes-the highest voting threshold for passing a budget of all the states. ${ }^{135}$ The constitution limits the amount of indebtedness that the state can incur to $\$ 300,000$ (unless the voters approve higher debt or it is necessary to repel invasion or suppress insurrection in time of war), ${ }^{136}$ effectively imposing a balanced budget. In March 2004, voters amended the constitution by passing an initiative to explicitly require that the legislature pass a balanced budget each year. Because voters decided through a popular initiative to impose legislative term limits in $1996,{ }^{137}$ it is inexperienced lawmakers that confront all of these difficult issues and high voting thresholds in the budget arena.

Thus, the fiscal and budget crisis in California that governors and lawmakers have faced over the past few years is the result in part of structural features of state and local government, many of which have been imposed by initiative. Not surprisingly, groups have turned to the initiative process again to change the structure of state government to allow lawmakers more flexibility to deal with difficult economic times. For example, in March 2004 voters were presented with the Budget Accountability Act, an initiative that would have reduced the supermajority required to pass a budget from two-thirds to $55 \%$, had it passed. ${ }^{138}$ The Schwarzenegger administration successfully asked the people to approve a $\$ 15$ billion deficit bond to deal with the state's immediate budget crisis; ${ }^{139}$ the initiative sweetened the deal for fiscally conservative voters by being tied to passage of another initiative that requires the legislature to pass a balanced budget and establishes a reserve fund. ${ }^{140}$ The important point here, regardless of the details

135 See Charlene WeAR Simmons, A Summary of Recommendations for Reforms to THE STATE Budget Process 6 (2002) (noting that nine states have supermajority requirements, but no other state requires a two-thirds vote).

${ }^{136}$ CAL. CONST. art. XVI, $\S 1$.

137 JOHN M. CAREy, TERM Limits AND LEGISLATIVE REPRESENTATION 12 (1996).

138 Cal. Attorney Gen., Ballot Title And Summary for Proposition 56 (2003), available at http://www.ss.ca.gov/elections/elections_bpd.htm (last visited Sept. 20, 2004).

139 CAl. Attorney Gen., Ballot Title and Summary for Proposition 57 (2003), available at http://www.ss.ca.gov/elections/elections_bpsupd.htm (last visited Sept. 20, 2004).

${ }^{40}$ Cal. Attorney Gen., Ballot Title and Summary for Proposition 58 
of these ballot questions and whether or not they passed, is that the recent poor performance of representative democracy in California is partly a consequence of the decisions made through initiatives that have substantially reduced lawmakers' options and changed politics in ways that make it less likely that lawmakers can respond effectively to fiscal challenges.

This analysis, indicting initiatives and referenda as causes of poor representative government, overlooks the more complex relationship between direct and representative democracy. Although certain structural changes put in place through popular votes may have made governing more difficult for state legislators and produced inexperienced lawmakers less able to make effective policy, the resurgence of direct democracy in the 1970s was partially the result of public disgust with and distrust of representative institutions. As a result, the public has approved initiatives and referenda that constrain lawmakers; some of those constraints may well improve the legislature, and some certainly make effective governing difficult. The relationship between direct democracy and traditional representative institutions is circular-each reacts to the other. Meaningful reform of either will require attention to both parts of the democratic system. For example, proposals to use direct democracy to change the process of redistricting for federal and state legislators are promising developments to harness direct democracy to improve representative bodies and to overcome the selfinterest of entrenched players.

A third interaction between direct and representative democracy was also apparent in the recall environment. Scholars have increasingly studied the effect of the existence of the initiative process on the laws considered and enacted by the legislature. Elisabeth Gerber and others have demonstrated that lawmakers in states permitting initiatives enact a different sort of legislation than do legislators in states without initiatives. Gerber terms this effect the indirect influence of direct democracy. ${ }^{141}$ She has concluded that, under certain conditions, legislation on issues that are likely to be the subject of popular

(2003), available at http://www.ss.ca.gov/elections/elections_bpsupd.htm (last visited Sept. 20, 2004); see also Donna Arduin, The Golden State, from Red to Black, WALL ST. J., Dec. 4, 2003, at A16 (explaining details of the Schwarzenegger proposal), available at 2003 WL-WSJ 68130029. The proposal for a hard spending limit she discusses was replaced by the balanced budget requirement as a result of compromise between the governor and Democrats. See infra note 157 and accompanying text (describing Schwarzenegger's acceptance of an initiative proposing a constitutional requirement that the legislature pass a balanced budget).

${ }^{141}$ See GERBER, supra note 18, at 50-58 (defining indirect influence as the use of the direct legislation process to pressure other actors to change policy). 
vote will be closer to the preferences of the median voter. ${ }^{142}$ When strategic lawmakers understand that their decisions can be second-guessed by voters if a ballot question is qualified, they take that reality into consideration when determining what laws to pass and the content of those laws. Lawmaking does not occur in a vacuum; it is affected by all parts of the political environment. ${ }^{143}$

Although Gerber's work suggests that the initiative process favors legislative outcomes close to the median voter's preferences, different conditions in the political environment can move the legislative outcome so that it is closer to outlying rather than median preferences. For example, if the voters likely to turn out in an election on a ballot question have extreme preferences, then the legislative response to head off a vote will be targeted at appeasing those interests, and not the median voter's. ${ }^{144}$

As this scholarship would predict, the reality of a recall affected the legislation that was passed by the Democratic legislature and signed by the governor. Compromise was reached in the summer of 2003 on a state budget in part because Davis and the Democrats wanted to "solve" the current budget crisis, albeit using indebtedness of dubious constitutionality, before the recall vote. Dozens of bills were passed in the waning days of the legislative session, often without committee hearings and through a process called "gut and amend." Using this technique, a bill that had gone through all the constitutionally mandated procedures was used as a shell with its language replaced by an entirely new and unrelated proposal that had not been considered by committee nor been available for lawmakers to analyze before floor deliberation and the vote.

${ }^{142}$ See Elisabeth R. Gerber, Legislative Response to the Threat of Popular Initiatives, 40 AM. J. POL. SCI. 99, 99-101 (1996) (evaluating "how other political institutions, besides elections, can induce legislators to respond to their constituents' preferences"); see also John G. MATsusaka, For the Many OR The FeW: The Initiative, Public Policy, AND AMERICAN DEMOCRACY 3 (2004) (summarizing findings that fiscal policies in states with initiatives reflect majoritarian preferences); John G. Matsusaka \& Nolan M. McCarty, Political Resource Allocation: Benefits and Costs of Voter Initiatives, 17 J.L. ECON. \& ORG. 413 (2001) (examining benefits and costs of allowing policy decisions to be made by voters rather than legislators).

${ }^{143}$ Note that this analysis suggests that absent the initiative process, lawmakers in California might not have allocated $30 \%$ of the budget to K-14 education as they were mandated to do by Proposition 98. See supra note 131 and accompanying text (finding that the majority of California's 2003-2004 budget that was earmarked by initiatives was spent in compliance with Proposition 98). On the other hand, interest groups like teachers unions usually ensure that a state spends a high proportion of its revenues on education, although perhaps not in ways that the people would prefer.

${ }^{144}$ See Matsusaka \& McCarty, supra note 142, at 424 (“[B]y taking away the representative's agenda-setting monopoly, ... . [a] moderate representative [may] adopt more extreme policies to accommodate an extreme interest group."). 
In many cases, these laws were not passed to placate the median voter, but instead they were passed to appeal to voters that Davis and Democratic legislators believed were likely to vote against the recall. The laws were intended both to convince relatively liberal voters that Davis, who as governor had pursued a somewhat centrist agenda, was responsive to their concerns and to encourage those voters to come to the polls. For example, after vetoing similar legislation before, Davis signed a law permitting undocumented workers to obtain driver's licenses. ${ }^{145}$ The legislation itself had not changed appreciably, and certainly not in a way to assuage Davis's earlier concerns. Instead, the threat of a recall prompted legislative action and gubernatorial approval in the hope that the action would influence the outcome of the election. Some of these actions may actually have hurt Davis in the election; for example, the driver's license measure generated significant opposition to Davis during the recall campaign. ${ }^{146}$ But miscalculation is also part of the political process and does not undermine the scholarly conclusion that politicians act in the shadow of direct democracy.

Interaction between direct and representative democracy will continue to be seen during Schwarzenegger's term. Schwarzenegger is a Republican facing a Democratic legislature and working on an agenda that runs counter to some legislators' priorities. Schwarzenegger has demonstrated that he is willing to resort to the initiative and referendum to enact his agenda over the next few years. In his first State of the State address, ${ }^{147}$ he announced that he would take workers compensation reform to the voters in the fall of 2004 if the legislature did not quickly send him an acceptable bill, which they soon did. He has organized a political committee to raise money for campaigns for ballot measures he supports, as well as for lobbying activities in Sacramento and for coordinating grassroots movements to further his policy agenda. ${ }^{148}$ "All of those kinds of reforms we want to put on the bal-

${ }^{145}$ S. 60, 2003-04 Leg., Reg. Sess. (Cal. 2003).

${ }^{146}$ Michael Gardner, Illegal-Immigrant Driver License Law Could Test Incoming Administration, SAN DIEGO UNION-TRIB., Oct. 10, 2003, at A1 (noting that $70 \%$ of voters in the recall opposed the law), available at http://www.signonsandiego.com/news/politics/ recall/20031010-9999_1n10license.html (last visited Sept. 20, 2004).

${ }^{147}$ Governor Arnold A. Schwarzenegger, State of the State Address (Jan. 6, 2004), available at http://www.nga.org/governors/1,1169,C_SPEECH^D_6310,00.html (last visited Sept. 20, 2004).

${ }^{148}$ See Dan Morain, Governor Will Raise More Funds, L.A. TIMES, Jan. 1, 2004, at B1 ("The campaign committees would allow Schwarzenegger to raise unlimited money for ballot measures and lobbying campaigns in the Legislature, as well as finance a possible reelection bid in 2006."). 
lot," he told the California Chamber of Commerce. "And it will take some pushing. It will take TV spots on there, which of course cost millions of dollars. So I will be coming back to you and saying, open your wallets again." ${ }^{149}$ This comment illustrates again how a hybrid system affects campaign finance regulations. It is ludicrous to think that Schwarzenegger is not as grateful to people who donate substantial sums to ensure passage of initiatives crucial to his electoral success as he would be if they donated directly to his reelection committee. And substantial sums are what the Governor has been requesting: to earn the title "California Recovery Team Chair," donors were asked for a $\$ 500,000$ contribution to the campaign to pass the $\$ 15$ billion bond. ${ }^{150}$ Certainly, this reality supports the FPPC's decision to extend contribution limits into the realm of some initiative committees. ${ }^{151}$

Schwarzenegger will not actually govern entirely by initiative, a strategy that does not allow for coordinated policy or thoughtful legislating on complex issues. Initiatives must comport with the singlesubject rule, their language cannot be changed as a result of compromise once they have qualified for the ballot, and they do not allow for continuous policymaking because voters come to the polls only a few times a year. Using ballot questions as a way to circumvent recalcitrant legislators occasionally may improve democratic institutions; using them as the main method of governing is inefficient, unwise, and impossible.

Schwarzenegger's rhetoric about resorting to initiatives if the legislature stands in the way of reform is a political strategy. He is making a credible threat that he will take issues to the people as part of his negotiations with an unfriendly legislature. His threat to use direct democracy was strengthened significantly in March 2004 by passage of two initiatives he actively supported, one authorizing a $\$ 15$ billion bond and one requiring a balanced budget from the legislature. ${ }^{152} \mathrm{He}$ spent millions on the campaign, convinced Democrats like Senator Dianne Feinstein to appear in advertisements for it, and neutralized the opposition that spent virtually no money making its case to the

\footnotetext{
${ }^{149}$ Nicholas \& Mathews, supra note 43, at A1; see also Evan Halper \& Peter Nicholas, Gov. Proposes Bond Measure of $\$ 15$ Billion, L.A. Times, Nov. 19, 2003, at A31 (noting that Schwarzenegger's staff has made it clear that "he is willing to put his ideas directly in front of voters if the Legislature balks").

${ }^{150}$ Dan Morain, Tickets to Schwarzenegger Fundraiser in New York Will Cost Up to $\$ 500,000$, L.A. Times, Feb. 5, 2004, at B8.

${ }^{151}$ See supra notes 45-46 and accompanying text (describing FPPC plan to limit contributions to ballot initiative campaign committees controlled by candidates and office holders).

${ }^{152}$ Supra notes $139-40$.
} 
public. ${ }^{153}$ His clout with voters was decisively demonstrated: before Schwarzenegger's active and personal campaign began, only about one-third of voters supported his bond, but it won decisively on Election Day. ${ }^{154}$

Lawmakers are pragmatic politicians. They understand that the recall reflects general voter distaste for incumbent politicians and politics as usual. They also know that Schwarzenegger's celebrity, wealth, and popularity may allow him to get around the legislature if they stand in the way of his policy agenda. Schwarzenegger's personal fortune, his ability to raise money, and the tremendous amount of publicity that surrounds his every move provide credibility to his threat to go over the heads of state lawmakers. Because Schwarzenegger successfully used direct democracy early in his term, his threat is especially powerful and likely to leverage compromise. Legislators and Schwarzenegger also know, however, that frequent use of direct democracy to enact laws is unwieldy and costly. Furthermore, even with the governor's popular appeal, success at the polls is not a sure thing. Thus, both sides-the governor and the legislature-have incentives to reach legislative compromises when the bargaining takes place in the shadow of the initiative and referendum process that a popular governor can use to great advantage.

Threatening to use direct democracy has already been a successful tactic with regard to several of Schwarzenegger's campaign promises. Within weeks of his taking office, the same Democratic legislature that passed the law permitting undocumented workers to get driver's licenses repealed it. They acted quickly both because they understood that this law had been extremely unpopular with voters and because they were aware that Schwarzenegger and his supporters would repeal the law through a referendum if the legislature ignored the popular will. By taking the lead, lawmakers sought to mitigate the fallout from their unpopular political decision, and they hoped to soothe supporters of the law by eliciting a promise from Schwarzenegger to discuss an "improved" version of the law. ${ }^{155}$

The influence of Schwarzenegger's credible threat to bypass the legislature also played a pivotal role in the negotiations with the legis-

${ }^{153}$ Rene Sanchez, Political Muscle: Schwarzenegger Demonstrates Strength with Ballot Triumph, WASH. POST, Mar. 4, 2004.

${ }^{154}$ See id. (describing how Schwarzenegger's political force was demonstrated in the "landslide" support for Propositions 57 and 58).

${ }^{155}$ See Nancy Vogel, Panel OKs Repeal of License Law, L.A. Times, Nov. 26, 2003, at B8 (noting Governor's promise to have an "open discussion" about a revised version of the bill in the future). 
lative branch about placing a $\$ 15$ billion deficit bond on the ballot. The California Constitution requires that a bond of that size be approved by the people, and the measure could appear on the March ballot only if the legislature agreed. If the Governor had been forced to qualify his proposal through the petition gathering process, the vote would have been delayed until November, which would not have been soon enough to avoid drastic budget cuts and substantial and costly short-term borrowing. Thus, the Governor needed the cooperation of the legislature, but lawmakers understood that if they did not reach an agreement, they could be circumvented, albeit at some cost. Negotiations broke off on the eve of the apparent deadline for placing a legislative initiative on the March ballot because Democrats would not agree to the hard spending cap proposed by the Governor and demanded by Republican legislators. ${ }^{156}$ Deadlines, however, can often be postponed, and in the next week of negotiations, Schwarzenegger agreed to back away from a hard spending cap and to accept instead a constitutional requirement that the legislature pass a balanced budget and establish a reserve fund to pay down the deficit bonds and to meet unexpected financial crises. Although this compromise upset some fiscal hardliners in the Governor's party, it gained enough votes to be sent to the people in the spring. ${ }^{157}$

Schwarzenegger's successful campaign to convince voters to pass the deficit bond and the balanced budget requirement was crucialnot just for the state's fiscal health, but also for Schwarzenegger's credibility in future negotiations. His strength in bargaining comes from his immense electoral popularity, financial resources, and ability to attract nearly constant media attention. With these tools, he can credibly threaten the legislature with government by initiative and has already proved he can translate those attributes into success at the polls. The Governor and his staff recognize the centrality of the initiative threat to his success as governor. When his advisers talk of the need to keep his popularity high, they do not talk just in terms of his reelection, but mainly about its effect on "his ability to push through other reforms by ballot initiative." ${ }^{158}$

${ }^{156}$ See Dan Morain \& Carl Ingram, Revived Fiscal Plan Goes to Ballot, L.A. Times, Dec. 13, 2003, at A1 (describing the initial proposal's "brush with death").

${ }^{157}$ See id. (reporting how an alliance with legislative Democrats provided Schwarzenegger a victory when the California Senate, by a one-vote margin, gave final approval for placing his plan before voters).

${ }^{158}$ Evan Halper \& Joe Mathews, Governor's Muscle Squeezed GOP First, L.A. TIMES, Dec. 13, 2003, at A1; see also Joe Mathews, Governor Tries to Tie Legislative Agenda to Bond Measure Coattails, L.A. TIMES, Feb. 12, 2004, at B6 (noting that Schwarzenegger is "try- 


\section{CONCLUSION}

The recall election is a dramatic variation on the long-running interplay between representative institutions and direct democracy. The recall has also cast new light on familiar issues relevant to the electoral process at the national level and in states without the recall process. It demonstrates the increasing use of lawsuits as a political weapon, and it provides perspective on questions that those working in the law of democracy have been studying-questions relating to political parties, independent candidates, and ballots. In short, the recall, when put into context, is not a radical departure, but it does provide a new way to frame for the analysis of difficult choices of design of democratic institutions.

ing to transform momentum from his campaign [on the bond measure] into legislative victories on workers' compensation, the state budget and rollbacks of business regulations"). 